\title{
ШЕНФЕЛЬДСКАЯ ВОЛОСТЬ: ИСТОРИЯ ВОЗНИКНОВЕНИЯ И ИСЧЕЗНОВЕНИЯ МЕННОНИТСКИХ ПОСЕЛЕНИЙ
}

\author{
Черказьянова И. В. Шенфельдская волость: история возникновения и исчезновения менно- \\ нитских поселений.
}

В статье реконструируется история Шенфельдской (Краснопольской) волости Александровского уезда Екатеринославской губернии, организованной в 1873 г., хронологически исследуются события 18601920-х гт. Волость отличалась тем, что все поселения на ее территории были частновладельческими, основаны меннонитами на купленных землях, она не имела четких границ, хутора располагались дисперсно. По уровню благосостояния жители волости выделялись среди других колонистов губернии. В центре внимания находится имение Зильберфельд как наименее изученное из числа поселений волости, а также судьба его владельцев. Экономии и хутора были разорены в годы Гражданской войны махновцами, в результате волость исчезла как административно-территориальное образование.

Ключевые слова: меннониты, Шенфельдская (Краснопольская) волость, Александровский уезд, Екатеринославская губерния, имение Зильберфельд, Гражданская война, семья Янцен, Нестор Махно.

Черказьянова І. В. Шенфельдська волость: історія виникнення та зникнення менонітських по-

У статті здійснена реконструкція історії Шенфельдської (Краснопільської) волості Олександрівського повіту Катеринославської губернії, організованої в 1873 р, Досліджуються події 1860-х - 1920-х рр. Волость відрізнялась тим, що всі поселення на ї території були приватновласницькими, засновані меннонітами на придбаних землях, не мала чітких меж, хутора розташовувалися дисперсно. Мешканці волості відрізнялись добробутом серед іиших колоністів губернії. У центрі уваги знаходиться маєток Зільберфельд та доля його власників. Економії і хутора були розорені в роки Громадянської війни махновцями, після чого волость зникла як адміністративно-територіальна одиниця.

Ключові слова: менноніти, Шенфельдская (Краснопільська) волость, Олександрівський повіт, Катеринославська губернія, маєток Зільберфельд, Громадянська війна, родина Янценів, Нестор Махно.

\section{Cherkazainova I. V. Wolost Schönfeld: Geschichte der Entstehung und des Verschwindens der Mennonitensiedlungen \\ Der vorliegende Aufsatz untersucht die Geschichte der Wolost Schönfeld (Krasnopol) Uyezd} (Verwaltungsbezirk) Alexandrowskij Gouvernement Ekaterinoslawskaja seit ihrer Gründung im Jahr 1873, chronologisch dargestellt im Zeitrahmen von 1860er bis in die 1920er Jahre. Das Besondere an dieser Wolost bestand darin, dass alle Siedlungen auf ihrem Territorium in privater Hand waren, von Mennoniten auf gekauften Grundstücken gegründet, die Wolost hatte keine festen Grenzen, die Bauernhöfe lagen weit auseinander. Das Wohlstandsniveau der Einwohner der Wolost war höher als das der anderen Kolonisten im Gouvernement Ekaterinoslawskaja. Der Fokus der Aufmerksamkeit liegt auf deın Gutshof Silberfeld, das Anwesen gehört zu den am wenigsten untersuchten, aber auch auf dem Schicksal seiner Besitzer. Während des Bürgerkriegs wurden viele Höfe durch Machno-Anhänger geplündert, als Ergebnis verschwand die Wolost als Verwaltungsgebiet.

Schlüsselwörter: Mennoniten, Wolost Schönfeld(Krasnopol), Uyezd(Verwaltungsbezirk) Alexandrowskij, Gouvernement Ekaterinoslawskaja, Gutshof Silberfeld, Bürgerkrieg, Familie Janzen, Nestor Machno.

Cherkazainova Irina. Shenfeld volost: the history of foundation and disappearance of the Mennonite settlements.

The author studies the history of the Shenfeld Mennonite volost foundation and destruction. The research tasks were as follows: to analyze the reasons of this volost establishing at the period of the colonist reform; to study development of the settlements at the second part of the $19^{\text {th }}$ century, to find out how its inhabitants participated in the modernization processes; to follow the cultural and spiritual life of the colonies and Aleksandrovsky district as

(C) И. В. Черказьянова, 2020 
a whole; to highlight the problem of the Mennonite settlements destruction. The Shenfeld (Krasnopolskaya) volost was situated in the Aleksandrovsky district of the Ekaterinoslav province. It was founded in 1873. Its uniqueness lays $\mathrm{m}$ the fact that it did not have definite administrative-territorial boundaries, since the possessions were dispersed. The population was made up of the Mennonites from Molochansk and (partly) Khortytsa colonies. The families settled on farms, united into small villages. The process of the eastern part of Aleksandrovsky district settlement was a part of the German colonization in this area and in the province as a whole. However, the volost differed from the other ones because it only consisted of private farms. Its economy was organized on the purchased (not granted by the tsars) land. The author pays attention to Zilberfeld estate that is the least studied settlement of the volost. The fates of its owners have not been researched yet. The volost was famous for its prosperity and contributed greatly into this region economy development. The destruction of an entire volost during the Civil War, that was the result of the Makhnovist movement, is also one of the important parts of its tragic history.

Key words: Mennonites, Shenfeld (Krasnopolskaya) volost, Alexandrovsky district, Ekaterinoslav province, Zilberfeld estate, Civil war, Yantsen family, Nestor Makhno.

Историография и источники темы. В последние десятилетия история причерноморских немцев привлекает внимание исследователей разных стран, в первую очередь историков Украины. История немецких и меннонитских колоний Екатеринославской губернии нашла отражение в монографических трудах $[10 ; 13 ; 16 ; 43]$, коллективных работах сотрудников Института украинско-германских исторических исследований Днепровского национального университета им. Олеся Гончара [27; 46]. Множество статей, освещающих различные стороны жизни колонистов Екатеринославщины и в целом Причерноморья, опубликованы на страницах ежегодного издания «Вопросы германской истории» (Днепр).

История волости заканчивается во время трагических событий Гражданской войны. Историография войны и махновского движения обширна, она нами не рассматривается. Обращаем внимание лишь на некоторые работы, посвященные положению немецких и меннонитских колоний в этот период [12; $14 ; 31 ; 66]$. Авторы статей анализируют вопросы политической жизни меннонитов, автономистского движения [2; 3; 4]. Важным вопросом истории меннонитов было их участие в вооруженной борьбе против махновцев, создание отрядов самообороны $[7 ; 8 ; 9$; 81]. Трагедию меннонитских поселений Николайпольской волости, 136 жителей которой погибли от рук махновцев, исследуют канадские ученые Х. Дик, Д. Стейплз и И. Тевс [87]. О жертвах среди меннонитов в ходе Гражданской войны регулярно публикует материалы канадский исторический журнал «Mennonite Historian») [67; 82].

В 1990-е годы, когда начался пересмотр истории махновщины, исследователи отказались от многих одиозных клише советской историографии в отношении крестьянского движения на территории Украины, но чаша весов начала клониться в сторону героизации самого Махно и его сподвижников. При этом на первый план начали выдвигать личные качества руководителя движения. Отношение махновцев к немцам-колонистам и меннонитам является неотъемлемой частьо истории этого периода, которая заслуживает более глубокого изучения.

История Шенфельдской волости до настоящего времени не стала объектом специального изучения. Небольшая работа «Schönfeld» [94], опубликованная в 1939 г. в Канаде потомком семьи Тевс, носит описательный характер, построена лишь на сохранившихся в эмиграции церковных хрониках и воспоминаниях жителей Шенфельда. Основное внимание автора сосредоточено на истории центрального поселения волости Шенфельда и судьбах отдельных людей. В настоящее время книгу Тевса можно рассматривать, скорее, как один из источников по истории волости.

При подготовке статьи использованы доступные, преимушественно опубликованные, источники: законодательные акты, земские документы (журналы, доклады и отчеты Александровской уездной земской управы и земского собрания), губернская и общероссийская статистика, памятные книги и другие справочные издания по Екатеринославской губернии. Важную роль в качестве источника играет пресса. Это немецкоязычные газеты колонистов «Friedensstimme», «Der Botschafter», русскоязычная газета «Екатеринославские губернские ведомости». Наибольшую ценность представляет газета «Friedensstimme», которая после запрета в 1914 г. снова появилась в 1917 г. и издавалась на протяжении всего периода Гражданской войны под разными названиями. Для реконструкщии истории школы привлечена информация из Российского государственного исторического архива (РГИА, Санкт-Петербург). Это материалы Комитета грамотности Вольного экономическо- 
го общества [50, ф. 91, оп. 3 , д. 368]. Использованы первичные материалы Всесоюзной переписи населения 1926 г., которые хранятся в Санкт-Петербургском филиале Архива Российской академии наук $[52$, ф. 135 , оп. 3 , д. 584]. Отдельные факты по истории волости и некоторых ее деятелей приводятся по опубликованным исследованиям $[30 ; 69 ; 75 ; 77]$. Привлечены германские и канадские генеалогические интернет-ресурсы [70; 90], архивы семей Янцен (Россия / Казахстан / Германия / Канада), Вильмсен (Россия / Германия / Канада), Дик (Германия / Канада).

Для реконструкции событий на территории Шенфельдской волости в период Гражданской войны были использованы воспоминания Н. Махно и его сподвижников, других очевидцев событий, материалы уже упоминавшейся газеты «Friedensstimme», документы научного сборника о махновском движении, подготовленного совместными усилиями архивистов России и Украины [38].

При подготовке публикации были поставлены задачи: проанализировать проблемы возникновения Шенфельдской волости в период проведения колонистской реформы, сюжеты развития поселений в мирное время и участия жителей волости в развитии экономики и духовной жизни колоний и Александровского уезда в целом; осветить проблему уничтожения меннонитских поселений в результате махновского движения.

Немецкие поселенцы в Александровском уезде. Условия приглашения иностранных колонистов при Александре I требовали, чтобы въезжающие переселенцы имели определенный достаток в виде денег или товаров. Поэтому колонисты, прибывшие в Россию в начале XIX в., изначально были более зажиточными, чем их предшественники времен Екатерины II. В этот период появилась большая группа меннонитских колоний на р. Молочной. Состоятельность меннонитов, их предприимчивость способствовали тому, что вскоре источником их благосостояния стали не только земледелие и ремесла, но и разведение овец и торговля. По мнению Н. В. Венгер, 1806 г. считается некой границей в развитии меннонитского предпринимательства $[16$, с. 159]. Меннониты взяли в общинное содержание переправу через Днепр в Кичкаском урочище, а Г. Вильямс, Г. Дик, П. Мантлер, В. Мартенс выстроили на Кичкаской верфи речное судно. Первая торговая экспедиция состоялась в том же году.

Существовавший в меннонитских колонияx закон о наследовании запрещал деление земельных наделов, а наследник, получивший право на имущество, выплачивал другим членам семьи долю в виде денежной компенсации. В итоге сам земельный надел как основа благосостояния не делился, а лишь прирастал новыми десятинами. Результатом стал рост числа безземельных колонистов и усиливающаяся имущественная дифференциация в материнских колониях. К началу 1860-х гг. более половины меннонитов остались без земли, а значительную долю среди наемных батраков уже в 1837 г. составляли сами меннониты. Малоземелье толкало колонистов на поиски новых мест для поселения и новых форм применения своего труда. Повышение благосостояния одних колонистов и малоземелье других способствовали тому, что первые искали возможность вложить свои капиталы, другие - возможности выхода из нужды, тем самым создавался потенциал для миграции трудовых ресурсов и капиталов. После отмены крепостного права помещики распродавали свои земли, не находя им нового применения, а будущие покупатели этих земель находились в близлежащих меннонитских колониях.

B XIX в. Александровский уезд Екатеринославской губернии активно заселялся немцами. К январю 1860 г., в течение 1840-1850$\mathrm{x}$ гг. только из молочанских колоний сюда переселились 73 семьи [90]. Основную часть новоселов составили жители Гуттерталя (34 семьи выехали в 1857 г.), отказавшиеся от общинного образа жизни. Среди поселенцев были выходцы из Шензее (9 семей), Либенау (4), Маргенау (4) и других. В 1859 г. в уезде проживали 7143 лютеранина и 2452 меннонита $[47$, табл. к с. 234]. К началу XX в. немцам поселянам-собственникам принадлежало $16,2 \%$ всей земли [ 25, с. 213$]$, численность меннонитов достигала 4488 чел., а число лютеран уменьшилось до 5983 чел. [59, с. 214]. По сведениям Александровского земства на 1904 г., в уезде существовало 192 немецких поселения, в которых проживало 8634 чел. $[28$, c. 408$]$. На 1 января 1915 г. немцам уезда принадлежало 164524 дес., что составляло $20 \%$ всей территории уезда [38, с. 54].

Отдельные колонисты также поселялись в городах, в частности в Орехове, который находился на границе Александровского и Бердянского уездов, а его жители были тесно связаны с землевладельцами Александровского уезда. Так, в 1827 г. в Орехове обосновался меннонит из Гальбштадта Вильгельм Мартенс, записавшийся в купцы 3-й гильдии. С 1848 г. здесь проживал Корнелиус Гейнрихс (из Шардау), с 1852 г. - мельник Петр Винс с родителями (из Руднервейде). В 1852 г. в горо- 
де числилось 19 меннонитов, которые владели семью предприятиями. В 1874 г. городским головой Орехова был избран Иван Андреевич (Генрихович) Янцен (1837, Шенвизе - 1901) ${ }^{1}$, оставался на этом посту 25 лет. На 1908 г. в городе действовала паровая мельница Ивана Ивановича Янцена (сына И. А. Янцена), производившая 250 тыс. пудов муки [58, с. 49].

Одновременно с покупкой земель меннониты создавали промышленные предприятия. В числе первых возникало производство обожженного кирпича, дорогого, но и более надежного материала, что закономерно связано с освоением новых участков и достатком новопоселенцев. По данным Александровской уездной земской управы за 1867 / 68 гг., У немецких колонистов уезда действовали заводы: черепичные и известняковые (4), уксусный, набивной и пивоваренный. Также имелись ветряные мельницы, маслобойни, кузницы, лавки [45, с. 98]. В 1874 г. при строительстве здания земства в Александровске кирпич и известь покупали у нескольких предпринимателей, в т. ч. на заводе Янцена (за кирпич уплачено 61 р. 20 к., за известь 377 р. 50 к.) $[40$, с. 115,120$]$.

К концу 1840-Х гг. в структуре сельского хозяйства Екатеринославской губернии господствовало скотоводство, преимущественно овцеводство. Посев хлебов был незначительный, под запашку отводилась десятая часть пригодных земель. Заметные перемены в сельском хозяйстве начались в 1850 -х гг., на первое место выдвинулось выращивание яровой пшеницы и льна. В хозяйстве колонистов Александровского уезда еще в 1860 е гг. преобладало тонкорунное овцеводство (29 663 овец на 1422 дворов), поскольку отрасль давала гарантированный доход в засушливом климате. Поголовье крупного рогатого скота насчитывало 6092 головы, кроме того, было зарегистрировано 6676 лошадей [45, ведомость № 11]. Пересыхание речек заставляло землевладельцев строить запруды, что требовало немалых затрат, в некоторых имениях разводили рыбу. Уже в начале 1860-х гт. отмечались успехи колонистов уезда в разведении садов, что нашло отражение в официальных изданиях. «В колониях иностранных поселенцев садоводство, - писал современник, - подобно всем отраслям сельской промышленности, в несравненно лучштем состоянии, чем у других сельских хозяев» $[51$, с. 144$]$. В начале XX в. самые обширные площади под садами в уезде были в Шенфельдской волости
(180 дес.), далее шли три волости: Александровская, Белогорьевская, Натальевская, в каждой из которых сады занимали по 100 дес. $[33$, c. 81]. Плодовое разнообразие колонистских садов убеждало скептиков в возможности разведения садов даже в засушпивой степной зоне.

В конце XIX в. промышленность уезда успешно развивалась. Важным центром стала колония Шенвизе близ Александровска, где действовали заводы сельхозмашин А. Я. Коопа, Леппа и Вальмана, Гильдебранта и Приса, мельницы «Нибур и $\mathrm{K}^{0}$ », пивоваренный завод Г. Г. Янцена. Крупнейшим предприятием был завод Коопа, оцененный в 1904 г. в 159381 р. 99 к. [5, с. 127]. Индустриализация коснулась и других волостей уезда, хотя и в меньших размерах. Так, в справочник «Вся Россия. Русская книга промышленности, торговли, сельского хозяйства и администрации» попали сведения о предприятиях Гуляйпольской волости: кирпичном заводе Я. А. Реймера (хутор Чистополь), машиностроительном заводе Я. Я. Кригера (с. Гуляйполе) [19, столбец $483,545]$. На хуторе Скелеватный Натальевской волости находился завод М. Я. Янцена, производивший сельхозмашины и оборудование на 15 тыс. руб. в год, на нем было занято 12 рабочих [63, с. 156-157].

Успехи немцев и меннонитов в сфере экономики находят косвенное подтверждение в документах органов уездного управления. Немецкие и меннонитские фамилии постоянно фигурируют в списках членов Второго городского по налогу с городских недвижимых имуществ присутствия (Александровск) и Второго раскладочного по промысловому налогу присутствия Александровского уезда. Причем в уездном присутствии меннониты представляли почти половину всего состава. 20 октября 1888 г. в уездное податное присутствие были избраны Г. И. Кран, Г. Г. Янцен, Ю. К. Янцен [29, с. 193]. В 1915-1916 гг. из семи членов трое были из числа меннонитских предпринимателей (Я. Я. Вибе, П. П. Прис, Г. Г. Янцен) [26, раздел Министерства финансов].

Немецкие школы возникли в уезде с первых лет основания поселений. В 1866/67 учебном году на 12717 жителей немецкой национальности приходилось 32 школы. Их посещали 1266 мальчиков и 1155 девочек (всего 2461 чел.). В среднем на школу в год тратилось 89 руб. [15, с. 253]. Для сравнения: в уезде проживало 151764 русских, у них было 62

\footnotetext{
${ }^{1}$ Супругой И. Г. Янщена была Шредер Екатерина Генриховна (20.09.1842-28.04.1926, Окречь), родная тетя депутата Государственной думы П. П. Шредера (1866-1942).
} 
школы с 1619 школьниками (1429 мальчиков и 190 девочек). Этим жителям школа обходилась в среднем в 51 руб. в год [15, с. 252]. Через 20 лет, в 1898 г. в уезде из 136 гाкол Министерства народного просвещения (МНП) 44 работали в немецких поселениях [44, с. 197]треть от общего числа (32,3\%). При обследовании земель в 1899 г. немцы показали самый высокий процент грамотности в уезде. Была установлена закономерность: колонисты, жившие на самостоятельно купленных землях, были наиболее образованными (на 1000 хозяйств выявлено 769 хозяйств с грамотным населением). У немцев на надельной земле показатель был несколько ниже - 684 хозяйства с грамотными. Всего по уезду средний показатель «грамотных хозяйств» равнялся 560 на тысячу хозяйств [33, с. 50]. По итогам школьной переписи 1911 г., в Александровском уезде школу посещали 1327 немецких детей (730 мальчиков и 597 девочек), в т. ч. 343 ребенка из меннонитских семей (196 мальчиков и 147 девочек) [41, с. 60].

Немцы и меннониты принимали активное участие в работе органов местного самоуправления. Уже на первом земском собрании Александровского уезда, проходившем 20-28 октября 1866 г., в качестве гласных избраны колонисты-меннониты А. К. Янцен, Н. Н. Зименс, Г. К. Янцен, А. И. Гиберт, В. В. Мартенс и колонист из Грунау Г. И. Штах [53, с. 273]. В 1869 г. на второе трехлетие был вновь избран Абрам Иванович Гиберт, поселенец из Шенталя. Среди уездных гласных, избранных на трехлетие, начиная с 1875 г., значится фамилия Я. А. Винса. После некоторого спада активности, о котором можно судить по количеству гласных, с 1887 г. меннониты были представлены шестью гласными, это - Гергард Вильгельмович Шредер, Вильгельм Генрихович Янцен, Петр Вильгельмович Нейфельд, Гергард Абрамович Классен, Франц Францевич Винс, Мартин Яковлевич Янцен.

Избранные в земство колонисты выполняли различную работу. Г. В. Шредер неоднократно становился членом уездной земской управы, постоянно участвовал в различных экспертных комиссиях. 10 октября 1906 г. П. В. Нейфельд был избран участковым попечителем по наблюдению за исправным содержанием балок и берегов рек. Членами сельскохозяйственного совета неоднократно избирались В. Г. Янцен и И. И. Фаст. Меннониты постоянно были среди заведующих военно-конскими участками. В целом Александровское земство характеризовалось, в противоположность, например, Павлоградскому («тихому»), «земством страстным».
Земство заслужило такую оценку, как отмечалось в одном из губернских отчетов, из-за той «стремительности, с какой в нем каждый вопрос дебатируется всеми почти гласными», а «земское собрание очень дружное, сплоченное в работе» [50, ф. 1288, оп. 3 (1912 г.), д. 72 , л. 98].

Шенфельдская (Краснопольская) волость: хозяйственная и духовная жизнь. В 1871 г. колонистская реформа отменила прежнее законодательство в отношении иностранных поселенцев. Среди важнейших изменений состоялась передача колонистов в общегубернское и уездное управление и перевод делопроизводства на русский язык. Закон оговаривал порядок преобразования бывшгих колонистских округов в волости: селения, входящие в состав округа, расположенного в нескольких уездах, образуют поуездно отдельные волости [49, т. 46, № 49 705]. В дореформенный период иностранные колонисты не входили в состав округов и волостей, имели собственное управление. В Екатеринославской губернии они относились к трем округам: 1-й Хортицкий (21 колония, из них в Екатеринославском уезде - 17, Новомосковском - 3, Александровском - 1), 2-й Мариупольский [Грунауский] колонистский (27 колоний) и 3-й Мариупольский [Бергтальский] меннонитский (5 колоний). После реформы в Александровском уезде появились две самостоятельные немецкие волости: Фридентальская (колонистская) и Шенфельдская (меннонитская). В тот же период произошло разделение Александровского и Мариупольского уездов. По закону 26 декабря 1872 г. уезды были разграничены. Как самостоятельный, Мариупольский уезд существовал c 1874 г. В ходе дальнейших преобразований Мариупольский колонистский округ был переименован в Александро-Невскую волость, а меннонитский - в Петропавловскую. Реформа предусматривала и создание у колонистов сельских обществ для решения хозяйственных вопросов. Это происходило на тех же основаниях, что и у других категорий крестьян. Они изложены в законе 19 февраля 1861 г. $[49$, т. 36, № 36 657]. В 1880-е годы шло формирование обществ для тех поселенцев, которые водворились после 1871 г. на правах частной собственности.

Шенфельдская волость состояла из селений и экономий, возникших в основном в 1860-70-е гг. В 1863 г. уже существовали хутора Альбрехтов (2 двора, 4 чел.), Классенов (4 двора, 15 чел.), Янцен (6 дворов, 13 чел.) $[32$, с. $146,151,157]$. Компактные поселения появились несколько позже. Поэтому часть 
сельских обществ волости объединяла хозяев, проживавших в одном поселке, в других случаях, как, например, с Зильберфельдским обществом, отдельные хутора объединялись вокруг наиболее крупного поселения, территориально оставаясь разрозненными имениями.

В 1876 г. в Шенфельдской волости насчитывалось 36 населенных пунктов (см. Приложение 1), в них числилось 347 душ мужского пола ${ }^{2}$. Наиболее крупными поселениями были Гуттердроф (38 муж.), Визенгоф (28 муж.), Брудергоф (20 муж.), Блюменштейн (19 муж.), Блюменфельд (17 муж.), Шенфельд (17 муж.), Зильберфельд (16 муж.). В 1890 г. в составе волости было пять селений, 181 двор и проживало 1245 чел. [64, с. 2-4]. В 1901 г. все население волости составляло 1609 чел., вся земля, принадлежавшая жителям (59 372 дес.), была купленной. Значительное сокращение числа населенных пунктов свидетельствует, на наш взгляд, как раз о процессе формирования сельских обществ, а не об исчезновении таковых.

Хутора часто носили собственные названия, в которых отражались особенности географического положения (Визенфельд, Гринфельд, Шенбрун, Эбенфельд, Рейнбах), именовались по фамилии хозяина или бывшего владельца земли (Мариенфельд, хутор Гейдебрехта, хутор братьев Тиссен), по названию ближайшего населенного пункта или географического объекта (Ковалиха, Соленая, Лиманский, Глиняный). В документах параллельно использовались названия как на немецком, так и русском языках (Шенфельд = Краснополье, Блюменфельд = Загорье, Кронберг = Михайловка, Зильберфельд = Сереброполье).

По итогам обследования 1899 г. (размер наделов) и 1908 г. (число жителей), в волости было шесть поселений: Краснополь (Шенфельд, 69 хозяйств, 17058 дес. удобной земли, 394 муж., 355 жен.), Вербовские хутора и пос. Блюменталь (23 хозяйства, 3725 дес., 70 муж., 63 жен.), Загорная (Блюменфельд, 20 хозяйств, 9005 дес., 167 муж., 166 жен.), Михайловка (Кронберг, 12 хозяйств, 1572 дес., 43 муж., 43 жен.), Сереброполь (Зильберфельд, 22 хозяйства, 19210 дес., 50 муж., 64 жен.), Яворская (Розенгоф, 43 хозяйства, 21774 дес., 271 муж., 268 жен.). Количество хозяйств увеличилось до 189 , численность населения составила 1954 чел. [60, с. 22-23].

Как правило, любая волость имела определенные границы. Здесь же были отдельные хутора и экономии, далеко стоящие друг от друга и от волостного центра, и даже располагавшиеся на территории русских волостей. Земельные владения шенфельдских поселян располагались как вблизи Шенфельда, так и в радиусе 30-35 верст от центра, некоторые земли находились в смежных волостях - Белогорьевской, Гуляйпольской, Заливянской, Преображенской. Хотя расстояния между земельными наделами иногда были незначительные и даже примыкали к уже имеющимся участкам, но в административно-территориальном отношении это была уже другая волость. С точки зрения управления отсутствие четких волостных границ создавало для уездных властей множество административных и хозяйственных проблем. Усложнялась работа и самого волостного правления. Планировка поселений тоже сильно отличалась от структуры материнских колоний. Здесь не было привычной центральной улицы с двухсторонней застройкой. Владения не располагались в одну линию, кто-то предпочитал выстроить дом ближе к реке или пруду, иногда напротив жилого дома высилась церковь.

$\mathrm{Ha}$ территории Шенфельдской волости проживали землевладельцы, приписанные к другим волостям и имевшие там недвижимость. Так, один из крупнейших хозяев, проживавший в Зильберфельде, - П. В. Нейфельд был поселянином колонии Фюрстенау Гальбштадской волости Бердянского уезда. Поселянка Гнаденфельдской волости Таврической губернии Е. И. Янщен реально проживала в Зильберфельде, а ее земля (437 дес.) находилась в Михайловской (Лукашевской) волости Екатеринославской губернии. Приписанный к Зильберфельду крупный предприниматель и землевладелец Г. А. Классен проживал на своем хуторе Бергфельд. Земля П. Н. Зименса (1124 дес.), поселянина Шенфельдской волости, была в соседней Белогорьевской волости. И. П. Дик, значившийся как поселянин Шенфельда, реально проживал в близлежащем поселке Шенбрун. Постоянные операции с землей, смена их владельцев, разделение земли между наследниками затрудняет учет реальных размеров владения отдельных поселенцев.

Земледелие оставалось главным занятием жителей волости. Овцеводство, приносившее большие доходы в первые годы, сокращалось в связи с освоением степей и сокращением пастбищ. В итоге пшеница «вытеснила» овец. Первые землемерные работы провели сами поселенцы Петр Нейфельд и Корнелиус Фри-

\footnotetext{
${ }^{2}$ Передень см. в Приложении № 1 к настоящей статье.
} 
зен, лишь в 1883 г. состоялось официальное межевание под руководством землемера Ларина. Первые ветряные мельницы в волости поставили Абрам Дридгер и Иоганн Фаст из Шенфельда. Позже на смену ветрякам пришли вальцевые мельницы с паровыми и керосиновыми двигателями, которые пользовались большой популярностью у русских землевладельцев.

Предприимчивые хозяева основывали заводы и фабрики, открывали магазины. Первыми в волости кирпичное производство организовали Корнелиус Эпп с Абрамом Завадским (Розенгоф) и Абрам Дридгер (Шенфельд). В 1886 г. в волости действовало пять кирпичных заводов (Шенфельд, Блюменфельд, Блюменгоф, Гольдшар, Розенгоф), паровая мельница в Блюментале. Первая кузнеца с литейным цехом была построена в 1884 г. в Шенфельде на средства Генриха Винса, производством заведовал Корнелиус Зименс. Пивоварением занимался Давид Иванович Шредер, производство было приписано к Зильберфельду. В 1916 г. Шредер имел на арендованной земле в с. Гуляйполе паровую вальцевую мельнишу, при ней электростанцию для освещения села и две усадьбы с домами и постройками. В целом же отсутствие компактных поселений, как это было на Хортице или на Молочной, приводило к тому, что промышленные предприятия в Шенфельдской волости были единичными, а основной промышленный потенциал меннонитов Александровского уезда был сосредоточен в самой крупной колонии Шенвизе или в русском селе Гуляйполе.

Религиозные общины волости являлись филиалом Лихтенауской общины, относились к церковным меннонитам. Церкви были построены в Шенфельде (1883), Блюменфельде (1891) и Розенгофе (1880).

Центральным поселением волости был Шенфельд (Краснополь), имевший неофици- альное название у меннонитов - Бразоль, по имени бывшего владельца участка Д. Н. Бразоля ${ }^{3} .20$ июля 1868 г. он продал им 5324 дес. Здесь находилось волостное правление, церковь, начальная шпкола, центральное училище, телефонная станция, магазины.

Первым волостным старшиной был Абрам Дридгер. Его преемниками стали И. П. Корнис ${ }^{4}$, И. П. Дик ${ }^{5}[73$, S. 8], Г. И. Винс. Первым волостным писарем был Петр Гардер (в 1885 г. переселился в Мемрик). Вслед за ним эту должность занимал Д. П. Дик (оставался на своем посту вплоть до исчезновения волости) ${ }^{6}$. Ремпель Франц Францевич был председателем волостного суда (сведения на 1916 г.), секретарем суда - Эннс Герман Корнелиусович (1916). 2 декабря 1902 г. освящено новое здание волости, в нем располагалась квартира волостного писаря.

В начале XX в. центральное отделение земской почты уезда находилось в Александровске, действовали 22 почтовьх пункта. Вплоть до 1912 г. почта в Шенфельд доставлялась из Гуляйполя. На сходе поселенцев 16 ноября 1912 г. было решено просить организовать, по примеру землевладельцев и коммерсантов Гайчура, почту и телеграф в Шенфельде. Одновременно был поднят вопрос о создании отделения Общества взаимного кредита. Для репения этих вопросов были избраны уполномоченные во главе с обершульцем Г. И. Винсом $[91$, S. 6]. Судя по земским отчетам, самостоятельное почтово-телеграфное отделение в Шенфельде так и не было открыто. Общество взаимного кредита действовало в Гуляйполе, его председателями и членами правления выступали предптиниматели ближайших хуторов-В. Г. Янщен, Д. И. Шредер, Я. П. Нейфельд.

Одним из старейших в волости поселков был Блюменфельд (Загорье, Загорянье), расположенный в пяти верстах на север от Гуляйполя. Он возник в 1846 г. (по другим данным

\footnotetext{
${ }^{3}$ Бразоль Дмитрий Никонович (1832-?), отставной поручик, дворянин Екатеринославской (1845) и Харьковской (1876) губерний, участник Крымской войны, первый председатель Екатеринославской губернской земской управы (с 1866), земский деятель Александровского уезда.

${ }^{4}$ Корнис Иоганн Петрович (20.03.1852, Орлов - 22.10.1915, Шенфельд), внук Петра Иоганновича Корниса (1791-1847), внучатый племянник Иоганна Корниса (1789-1848), сын Петра Петровича Корниса (1823-1885). Первая жена Маргарита Классен (1855-1906), свадьба проходила в Шенфельде 2 ноября 1876 г., умерла в Харькове, похоронена 24 февраля 1906 г. в Шенфельде. В первом браке было 10 детей, все дети родились в Шенфельде. Младший сын Петр убит махновцами 25 января 1919 г. Вторая жена Катарина Варкентин (1862-1945, Канада).

${ }^{5}$ Дик Иоганн Петрович (1857 - 18 октября 1914), волостной старшина (1897-1909), один из основателей и житель Шенбруна (1885). В первом браке прожил недолго, во втором - 23 года, имел приемного сына Корнелиуса Эннса. О И. П. Дике см.: Ehemaliger Oberschulze der Schönfelder Wolost J. P. Dick † Friedensstimme. 1914. 1. November. S. 8.

${ }^{6}$ Дик Давид Петрович (ок. 1852-1927, Новополь), волостной писарь, первый опыт службы в волостном правлении он приобрел в Галббштадте, пользовался огромным уважением среди жителей волости, был женат на Марии Петровне Нейфельд (с 1874), дочери П.Я. Нейфельда, имели трех детей. Жили в новом здании волостного правления. В 1912 г. арендовал землю, занимался еще и хлебопашеством. В 1920-е годы переселился в Западную Сибирь, сначала семья поселилась в Алонском, позже основали хутор Новополь (Нейфельд) близ Пучково под Омском.
} 
- в 1848 г.). Среди основателей были представители так называемой «семьи четырех братьев Янцен» из Петерсхагена: Петр Яковлевич, Яков Иоганнович, Абрам Корнелиусович и Яков Яковлевич Янцены. В 1856 г. к ним переселились Иоганн Дридгер, Абрам Валл, Яков Янцен и Дитрих Янцен [94, S. 7-8]. В 1859 г. в Блюменфельде насдитывалось 12 жителей, в 1885 г. - 72, в 1897 г. - 133, 1908 338,1918 г. -395 [35, с. 57]. Фамилия Янцен в этом поселении доминировала всегда - в начале XX в. ее носили 14 чел. Это - Иван Петрович (142 дес.), Абрам Петрович (142 дес.), Яков Иоганнович (291 дес.), Франц Абрамович (285 дес.), Дитрих Абрамович (200 дес.), Иоганн Абрамович (400 дес.), Петр Яковлевич (285 дес.), Иоганн Яковлевич (818 дес.), вдова Якова Янцена (500 дес.), Корнелиус Абрамович (498 дес.), Петр Абрамович (375 дес.), вдова Дитриха Янцена (213 дес.), Абрам Абрамович (137 дес.), Корнелиус Иоганнович (362 дес.) [22, с. 18-19]. В 1873 г. был избран первый проповедник - Дитрих Янцен.

К сельскому обществу Розенгоф (Яворская) относились несколько хуторов и имений: Розенгоф, Тигенгоф, Блюменталь, Соленая, Гохфельд, Шенберг и др. Первыми поселенцами Розенгофа были Гергард Винс из Ней-Гальбштадта и Петр Тиссен. Экономию Гохфельд основал владелец мельницы Генрих Тиссен из Екатеринослава, купив 2000 дес. В 1885 г. на хуторах Розенгофа проживали 32 чел., в 1905 г. - 419 [35, с. 344].

В 1910-е гг. на территории волости имелось 14 школ, включая центральное училище в Шенфельде. Согласно официальной статистике учебного ведомства, на территории волости школы действовали: Шенфельд (с 1874), Тигенгоф (1876), Михайловка (Кронсберг, 1879), Вербовские хутора (1883), Сереброполье (1889), Шенбрун (1891). В 1894 г. появилась Софиевская фабричная школа, в 1895 г. - Яворская. В 1897 г. школа учреждена в Гохфельде, в 1901 г. - на хуторе Эбенфельд [62, выборка]. Школа в Блюменфельде появилась в 1848 г., а в 1891 г. для нее было выстроено новое здание. Чаще всего занятия с детьми были организованы задолго до регистрации школы, поэтому дата официального открытия школы и время начала школьных занятий в колониях, как правило, расходятся, иногда на несколько лет.

Меннонитские школы, основанные выходцами Гальбштадского округа за пределами округа (в Херсонской губ., Крыму и Александровском уезде), как и в самом округе, с 1869 г. были подчинены в учебном плане Молочанскому меннонитскому училищному совету (действовал до 1919 г.). До начала колонистской реформы в хозяйственном отношении школы находились в ведении Министерства государственных имуществ (МГИ). Но и после передачи колоний в общегубернское управление школы еше некоторое время оставались в ведении МГИ, с 1881 г. началась поэтапная передача колонистских школ в МНП. Законом 2 мая 1881 г. центральные училища меннонитов и их начальные школы переходили в подчинение МНП, но деятельность совета не прекратилась, в ближайшем заведовании совета оставались вопросы духовного воспитания детей, деятельность учителя, проведение учительских конференций.

Согласно официальной хронике, школа в Шенфельде открыта в 1874 г., но сельская хроника констатирует, пто первые занятия для детей Шенфельда начались в 1870 г. под руководством учителя Зименса, они проходили в летних постройках Петра Петровича Корниса $^{7}$. Через год шाкола перебазировалась в имение Дридгера, тогда же учителя Зименса сменил Вильгельм Петрович Нейфельд ${ }^{8}$ [65], но и он нерез год выехал в Гальбштадт.

В 1910 г. в Шенфельде официально открылось трехклассное центральное училище. Для учреждения учебного заведения было создано общество в поддержку училища Шенфельдской волости. Фактидески училище начало действовать еще в 1907 г., первым учителем был Ремпель Герман Абрамович9. Второго учителя пригласили из Ладекопа - Дика Якова Яковлевича. Вначале занятия проходили в помещении церковной школы, а позже в доме для учителей, построенного на средства родителей. Теснота и невозможность разместить всех желающих заставили общество озаботиться строительством специального здания для пентрального училища. Для решения задачи было избрано правление в составе: председатель, землевладелец Вильгельм Генри-

\footnotetext{
${ }^{7}$ Корнис Петр Петрович (14.09.1823, Орлово - 4.03.1885, Шенфельд), племянник Иоганна Корниса (1789-1848). Переехал из Орлово в Шенфельд в 1868 г.

${ }^{8}$ Нейфельд Вильгельм Петрович (12 ноября 1856, Гнаденфельд - 7 июня 1923, Ридли, США), учитель, проповедник, автор учебников, единственный сьн основателя типографии в Гальбштадте П.Я. Нейфельда (1829-1909). В 1898-1911 гг. преподавал в центральном училище в Гальбштадте, руководил хором. В 1911 г. эмигрировал с семьей в Америку.

${ }^{9}$ Во время Первой мировой войны Г. А. Ремпель служил санитаром. Скончался от тифа в Брест-Литовске 15 мая 1915 г.
} 
хович Янцен (Зильберфельд), землевладелец Яков Петрович Нейфельд (Эбенфельд), проповедник Яков Леонгардович Дик (Визенфельд) и обершульц Иоганн Петрович Дик (Шенбрун). Члены правления и строительной комиссии, а также учителя начали поиски приемлемого архитектурного плана. В итоге за основу взяли проект центрального училища в Спате (Крым), открывшегося 14 ноября 1906 г. Здание было готово в начале сентября 1909 г., в октябре освящено. Одновременно был приглашен третий учитель - Абрам Тевс.

Учительский персонал центрального училища часто менялся. С 11 июля 1910 г. заведующим был назначен Ф. Ф. Эрлер [57, с. 154], он заменил уволившегося $Г$. А. Ремпеля. Летом 1912 г. газета «Friedensstimme» неоднократно публиковала объявление о поисках учителя для Шенфельдского училища вместо выбывшего А. П. Тевса. В 1913/14 учебном году школу возглавлял Петр Петрович Завадский (с содержанием 1300 руб. в год). В тот год обучалось 75 юношей. Под руководством Завадского работали учителя Генрих Дитрихович Нейфельд, Гергард Петрович Шредер, Яков Иванович Дик. Самыми опытными из них были Дик и Нейфельд, имевшие к тому времени 10-летний педагогический стаж [48, c. 425-426]. В дальнейшем учителями работали Сусанна Левен, Елена Фрезе, Яков Тиссен, Яков Нейфельд. Школьные занятия заканчивались, как правило, в первой декаде мая, но уже до их окончания проводились приемные экзамены на новый учебный год.

До появления в Шенфельде специального здания для молитвенных собраний верующие собирались по воскресным дням в доме Д. Корниса. Первым проповедником в общине был Иоганн Фаст из Лихтенау. 12 января 1872 г. состоялись первые выборы проповедников, ими стали Нейфельд Петр Герхардович и Гюберт Арон. Последний вскоре скончался, и до 1877 г. Нейфельд служил один. После его смерти в 1898 г. (в возрасте 64 лет) общину возглавил Дик Яков Леонгардович ${ }^{10}$, прибывший из Блюменштейна в 1888 г. О возросшем статусе шенфельдской обшины свидетельствует тот факт, что в сентябре 1909 г. в Шенфельде проходила всеобщая конференция меннонитов.

Своего духовного старшины в Шенфельде никогда не было, их окормлял старшина из материнской колонии. Когда в годы Гражданской войны Шенфельд оказался отрезанным от церковной общины Лихтенау, прихожане обратились с просьбой к духовному старшине Иоганну Классену из Шенвизе, чтобы он взял под свою опеку новых прихожан. Классен совершал важнейшие обряды в этот сложный период, под его руководством 28 июня 1918 г. прошло последнее крещение в Шенфельде. 14 сентября 1919 г. в последний раз прошла полноценная церковная служба.

Зильберфельд и его владельцы. Сельское общество Зильберфельд (Сереброполе, Сереброполье, Серебряное Поле) представляло собой совокупность поселений на территории между железнодорожными станциями Пологи и Гуляйполе. Его владельцы играли заметную роль в жизни Шенфельдской волости. Интерес к этому поселению вызван и тем, что, по мнению некоторых исследователей, Зильберфельд был, пожалуй, самым первым меннонитским поселением в этой части Александровского уезда [89, S. 348-349]. Факты свидетельствуют о том, что в 1859 г. на карте Александровского уезда значились четыре хутора будущей Шенфельдской волости: Зильберфельд (9 дворов), Гринфельд (2), Блюменфельд (1), Классена (4) [54, с. 20, 32]. Самым крупным из них был Зильберфельд, он стал своеобразной точкой роста.

Официальной датой основания Зильберфельда считается 1843 г. [35, с. 147]. Поселение появилось на земле, купленной Генрихом Петровичем Янщеном (30.11.1792 - 13.09.1867) у помещика Серебрякова в конце 1830 -х годов (3000 дес. по цене 3 руб. серебром за десятину).

Г. П. Янцен («Генрих Янцен из Шензее»), проживавший в Шензее с 1823 г., был из числа крупных предпринимателей первой половины XIX в., один из первых среди меннонитов, обогатившихся торговлей. Вместе с другом и соратником Иоганном Корнисом брал в аренду запасные земля под распашку по минимальной цене. Известно, что в 1842 г. Генрих участвовал в торгах на аренду земли (с 24 мая 1842-го по 24 мая 1845 г.) при Молочанском меннонитском округе $(20317 \text { дес. } 783 \text { саж.) })^{11}$ $[19$, ф. 6, оп. 1, д. 5914]. В Шензее Янцен владел магазином и торговал древесиной, был заводчиком крупного рогатого скота. В 1842 г. с доходов от этих занятий приобрел земельный

\footnotetext{
${ }^{10}$ Дик Яков Леонгардович, проповедник в Лихтенау (с 1 марта 1881 г.), в 1888 г. переехал в Шенфельд, в 1889 г. избран старшим проповедником общины. Одним из последних покинул разоренный махновцами Шенфельд. Умер 19 января 1922 г. в Нейкирхе.

${ }^{11}$ Копию дела «Об отдаче в откупное содержание земли, состоящих при колониях Молочанского меннонитского округа» любезно предоставила В. В. Солодова (Одесса).
} 
участок в 2045 дес. [69, S. 407,408, 411]. В 1848 г. был зачислен в купцы Бердянска, при этом сохранял статус колониста [16, с. 224]. Другими крупными землевладельцами в это же время были: Иоганн Корнис (5864 дес.), Вильгельм Аронович Мартенс (3691), Давид Исаакович Шредер (3000), Винс (3000), Классен (1300) [30, с. 55].

Материалы ревизий позволяют в общих чертах воспроизвести сведения о предках Генриха Петровича. Известно, что его дед Корнелиус Янцен (ум. ок. 1793-1795) с женой Сарой (род. ок. 1736) и четырьмя сыновьями въехал из Тигенхагена на Хортину в 1789 г., предположительно сразу в Эйнлаге. Данные ревизии 1795 г. свидетельствуют о том, что вдова Сара Янцен с двумя неженатыми сыновьями Петром и Генрихом Корнелиусовичами проживала в Эйнлаге [96, S. 239]. Во время ревизии 1814 г. уже сам Генрих Петрович Янцен с женой числился в Нижней Хортице. Состав семьи Янцена в первом браке с Анной Гамм известен по материалам генеалогического сайта GRANDMA ${ }^{12}$. Янцен был похоронен в Зильберфельде 17 сентября 1867 г.

Г. П. Янцен, занимаясь разведением овец и торговлей, постоянно расширял земельные владения. К коншу жизни он имел 20 тыс. десятин земли, около 30 тыс. овец и ежегодный доход в 100 тыс. руб. [77, Р. 189]. Зильберфельд стал родовым имением для нескольких поколений Янцен, а хутор положил начало формированию поселка с тем же названием.

Авторы книги «Diese Steine», основываясь на семейных хрониках и воспоминаниях, утверждают, что основание Зильберфельда в 1839 г. связано с семьей Михаила Янцена [89, S. 348-349]. Известные нам факты говорят о том, что Михаил Генрихович Янцен (род. ок. 1819), старший сын Генриха Петровича, с семьей покинул колонию Шензее в 1837 г., один из его сыновей Петр родился в Гнаденфельде в 1850 г. В 1890 г. М. Г. Янцен, поселянин-собственник колонии Шензее Бердянского уезда, владел землей в Мариупольском уезде $(761$ дес.). Позже следы этой семьи прослеживаются в бергтальских колония $^{13}$. Мариупольского уезда, в Тащенаке (имение Эльбинг) Мелитопольского уезда, a также в Крыму (имение Киргиз, Перекопский уезд). Имеющие у нас сведения пока не доказывают причастность самого Михаила Янцена к основанию Зильберфельда. Вероятно, понятие «семья» толкуется авторами в пиироком смысле. Для выяснения этого вопроса нужны углубленные архивные исследования.

Отдельные факты говорят о том, что земли, принадлежавшие Г. П. Янцену, активно заселялись в 1840-50-е гг., можно предположить, что отчасти на правах аренды. В начале 1850-х гг. девять семей из молочанских колоний поселились в имении Янцена [83]. Среди них значатся: два управляющих имением Янцена - Генрих Унгер (39 лет, из Рюккенау, 6 детей) и Петр Нейфельд (51 год, из Либенау, двое приемных детей), два мельника - Франц Дерксен (38 лет, из Либенау, 4 ребенка) и Петр Тевс (32 года, из Тиге, двое детей), учитель Петр Дерксен (56 лет, из Фишау, трое детей). Остальные поселенцы занимались сельским хозяйством (Мартин Гоосен из Либенау, Мартин Регир из Шензее, Франц Фогт из Контениусфельда, Мартин Леткеман из Либенау).

В официальных данных статус Зильберфельда строго не зафиксирован: он называется то хутором, то колонией, а сведения о количестве жителей постоянно меняются. В 1859 г. Зильбер Фельд (Верхний Жеребец) Александровского уезда именуется владельческим хутором. Он находился при балке Жеребец, в 58 верстах от уездного города Александровска и в 16 верстах от становой квартиры, в нем насчитывалось 9 дворов, проживало 13 мужчин и 15 женщин $[54$, с. 20]. Возможно, девять дворов - это жилье первых девяти семей, переселившихся в имение Янщена. Почтовым адресом было с. Гуляйполе. В 1862 г. на хуторе Янцен (Зильбер-Фельд) имелось 6 дворов и проживало 13 чел. [32, с. 149]. К январю 1872 г. на хуторе значились три души мужского пола «из разных колоний Бердянского уезда», которые оставались приписанными к коренным колониям [59, ф. 381 , оп. 13 , д. 7813 , л. 101 об.]. В статистическом описании южных губерний за 1886 г. появляются сведения о немецкой «колонии», расположенной в вершине речки Жеребец, с одним двором и семью жителями [17, с. 24]. Вероятно, речь идет о какой-то уже выделенной наследникам части из общего владения.

После введения в России в 1874 г. закона об обязательной военной службе многие меннониты в знак протеста эмигрировали. Семьи из Зильберфельда, выехавшие в 1870-е годы в Манитобу (Канада), основали там поселение с таким же названием [89, S. 349]. На Алтае по-

\footnotetext{
${ }^{12}$ Доступ на сайт GRANDMA ограничен. Выборку с сайта по нашей просьбе любезно предоставил Андрей Крысанов (Россия).

${ }^{13}$ В Бергфельде наследникам Янщена Михаила Генриховича принадлежало 760 дес.
} 
селение с аналогичным названием возникло в годы столыпинской реформы ${ }^{14}$ [98].

В конце XIX в. хутор Сереброполь (Зильберфельд) делился на три части. Хутор № 1 (901 дес.) принадлежал Вильгельму Генриховичу Янцену (1858-1919). Хутор № 2 (912 дес.) был собственностью детей покойного Якова Генриховича Янцена (1854-1885), старшего брата В.Г. Янцена - Генриха (1881-?) и Абрама (1884-1917) Яковлевичей. Третья часть была в собственности сестры Вильгельма и Якова - Аганеты Генриховны Янцен (муж Петр Вильгельмович Нейфельд, 910 дес.). Кроме того, в 1899 г. оставалась еще неразделенная часть наследства Г.П. Янцена (2654 дес.). В 1913 г. одновременно указаны и экономия Зильберфельд, и хутор братьев Янцен, оба находились в 10 верстах от Гуляйполя. В первом случае отмечены пруд и колодец, 5 дворов, 6 муж. и 5 жен., 5345 дес., школа, владельцы Янцен, Нейфельд и другие. Во втором - колодец, 2 двора, 10 муж. и 10 жен., 1048 дес. [18, с. 55].

Из приведенных сведений можно сделать вывод, что владельцами имения Зильберфельд всегда оставались лишь наследники Г. П. Янцена, а в число жителей могли попасть и те, кто арендовал землю у владельцев или временно проживал рядом. Арендаторы могли состоять в родстве с владельцами имения. Зильберфельд был родиной Генриха Иоганновича Янцена (1885-1933, Калантаровка), сына Иоганна Корнелиусовича Янцена (1843-1910, Лихтфельд; в 1905-1922 гг. семья И. К. Янцена жила в Ней-Шензее). В Зильберфельде родились сестры Шперлинг, обе в замужестве Янцен: Елена (26 марта 1914) и Елизавета (1916), три дочери Генриха Кетлера - Екатерина Шредер, Мария Нейфельд, Елена Классен. Последние получили в наследство крупные земельные владения по соседству с Зильберфельдом.

Часть земель Янцена была продана еще при жизни основателя Зильберфельда и на них возникли новые поселки: Винтергрюн (близ Белогорья), Гринфельд и Генрихсфельд (Александровка).

Винтергрюн находился в 14 верстах от Орехова. Сначала арендатором, а позже первым владельцем стал Иоганн Иоганнович Гоосен (1817-1891), муж Катарины Генриховны Янцен (1825-?), одной из дочерей Г. П. Янцена. Супруги Гоосен со старшими детьми переселились из Шензее в 1852 г., в Винтер- грюне родился их четвертый ребенок Яков. В 1899 г. имение разделено на пять участков, новыми владельцами стали: сын первого владельца Яков Гоосен (791 дес.), Генрих Абрамович Янцен и вдова Мария Петровна Кетлер (640 дес.), Иоганн Яковлевич Янцен (334 дес.), Вильгельм Генрихович Янцен (Зильберфельд) (150 дес.), Яков и Иоганн Петровичи Вальман (1200 дес.). В Генрихсфельде, на купленных землях, вначале поселились восемь семей, в 1900 г. их число увеличилось до 18, у них было 950 дес. Летом 1900 г. вся земля была продана, и в сентябре 1900 г. 12 семей (48 пел.) переселились в Самарскую губернию [89, S. 349]. В 1859 г. Гринфельд представлял собой хутор при р. Гайчул с двумя дворами, где проживали 17 чел. [54, с. 20].

С появлением сельских обществ у колонистов Шенфельдской волости под некоторыми названиями подразумевается уже несколько хуторов, приписанных к одному из наиболее крупных. В состав сельского общества Зильберфельд, кроме центрального хутора, входили имения: Эбенфельд (Гергард Гергардович и Екатерина Генриховна Классен; Яков Петрович и Мария Генриховна Нейфельд, 2 двора), Бергфельд (Дитрих Дитрихович Фризен и П. Тярт, 2 двора), имение наследников Альбрехта (4 двора), имение наследников Давида Ивановича Шредера (2 двора), общее владение братьев Гоосен, вдовы Маргариты Генриховны Винс и Якова Нейфельда (4 двора). В 1918 г. на территории сельского общества проживали 137 чел.

В 1897 г. землевладение Серебропольского общества было самым крупным в уезде и составляло 21124 дес. Для сравнения, в Шенфельдском обществе было 65 дворов, и 11628 дес. $[59$, с. $14-15]$. В 1899 г. к сельскому обществу Зильберфельд относились 24 двора, проживало 87 чел. (49 муж. и 38 жен.), в собственности владельцев находилась 21801 дес. $[55$, c. 20]. На 1 января 1902 г. в ведомости для содержания лесных команд к Зильберфельду были отнесены: Альбрехт Дитрих Абрамович (225 дес., ветряная мельница), Альбрехт Маргарита Томасовна (ветряная мельница), Винс Герхард Яковлевич (381 дес.), Винс Маргарита Андреевна (748 дес., ветряная мельница), Винс Яков Андреевич (93 дес.), Зименс Николай Генрихович (381 дес.), Классен Гергард Гергардович (1475 дес., чугунно-литейный завод, паровая мельница, ветряная мельница, кирпидный завод), Мартенс Давид Вильгель-

\footnotetext{
${ }^{14}$ Винс, автор заметки в одном из номеров газеты «Friedensstimme» за 1911 г. сообщал, пто их поселение основано весной 1911 г. на государственном участке № 86, в 40 в. южнее Барнаула. Обосновались 35 семей, но успели засеять поля лишь некоторые, т. к. многие прибыли весной или даже летом.
} 
мович (1575 дес., ветряная мельница), Нейфельд Яков Петрович (1540 дес., винокуренный завод), Унру Петр Тобиасович (1127 дес., ветряная мельница), Шредер Давид Иванович (1680 дес., винокуренный завод), Янцен Вильгельм Генрихович (1520 дес., ветряная мельница), наследники Якова Генриховича Янцена $(1520 \text { дес. })^{15}[22$, с. 19].

С именем основателя хутора Генриха Янцена связана и организация школы в Зильберфельде, она существовала с $1851 \Gamma^{16}{ }^{16}[50, \phi$. 91 , оп. 3 , д. 368 , л. $356-359$ об.]. Это зафиксировано в анкете школы во время обследования шшкол Комитетом грамотности ВЭО в январе 1895 г. С другой стороны, как уже отмечалось, в 1851 г. среди первых поселенцев в имении Янцена был учитель Петр Дерксен. Это было начало занятий, а официально школа была зарегистрирована в 1889 г.

Школьное здание принадлежало семъе Янцен, которая бесплатно предоставила для занятий один из своих домов. Это была каменная постройка под железной крышей, с двумя окнами. Учебное помещение состояло из одной комнаты (ширина 4 м, длина 8,5 м, высота потолка - 2,8 м). В 1890-е гг. попечителем школы был землевладелец Петр Вильгельмович Нейфельд, муж Аганеты Генриховны Янцен, имел среднее образование. Школа получала от собственников хутора помощь натурой приблизительно на 50 руб. Содержание школы в 1894 г. составило 525 руб. в год, в т. ч. 400 руб. шло на жалование учителю, на отопление - 25 руб., на покупку школьной мебели - 25 руб., на приобретение книг - 15 руб. Обучение было платным, со всех детей взималось по 10 руб. в год.

Учебный год традиционно начинался 1 сентября, заканчивался 1 мая. Дети учились в одну смену, вечерних и воскресных занятий не было. Закон Божий и немецкая грамота велись на немецком языке, особое внимание учитель уделял русскому языку и арифметике. Ручного труда и обучения ремеслам не было. Пение и гимнастику учитель вел бесплатно.

Детей принимали в школу ежегодно в течение всего учебного года, что важно отметить. Обычно прием проходил раз в два года там, где не набиралось необходимое количество детей, т. к. общество не хотело тратить дополнительные средства на содержание учите- ля. По данным на 17 января 1895 г., по списку в школе значились 23 ученика (16 мальчиков и 7 девочек). Это были дети 8-15 лет (8 лет - 2 мальчика, 9 лет - 3 мальчика, 10 лет - 3 мальчика, 2 девочки, 11 лет - 3 мальчика, 2 девочки, 12 лет -2 мальчика, 2 девочки, 15 лет -1 девочка). Из немецких семей было 20 детей (13 мальчика и 7 девочек), по вероисповеданию они делились на меннонитов (8 мальчиков и 3 девочки), лютеран (3 мальчика и 3 девочки), католиков (2 мальчика и 1 девочка). По социальному составу родители детей относились к поселянам-собственникам (колонистам) (8 мальчиков и 3 девочки), мещанам (1 мальчик и 1 девочка), иностранцам (4 мальчика и 3 девочки). Из Зильберфельда школу посещали 15 детей (9 мальчиков и 6 девочек), они ежедневно приходили из дома. Восемь учеников проживали на квартирах. Это были дети из соседних селений, расположенных на расстоянии 3-4 верст (3 мальчика), 5-10 верст ( 2 мальчика и 1 девочка) и более 10 верст (2 мальчика). Известны имена отдельных учеников Зильберфельда [84]. Это Генрих Яковлевич Кетлер (род. 14 июня 1883, Гроссвейде), штколу окончил в 1896 г., аттестат об окончании школы подписал учитель Генрих Кетлер. Генрих Яковлевич Янцен (род. 11 августа 1881 , Зильберфельд) получил аттестат об окончании школы в сентябре 1895 г., документ подписал учитель Генрих Янцен.

В январе 1895 г. в шкколе имелось 16 учебников и 7 учительских пособий. Закон Божий преподавался по учебнику Л. Вангемана «Библейская история», немецкий язык - по учебнику К. Унру «Jugendfreund» и «Sprachlehre» Юнггама. Для занятий по русскому языку использовались книги М. Вольтера «Русская речь» и Д. Тихомирова «Грамматика», по арифметике - учебник А. Гольденберга. По географии учебников не было. Из наглядных пособий в наличии имелись географические карты, атлас, глобус, счеты. Библиотеки для внеклассного чтения не было, не было в имении и сельской библиотеки. Газет и журналов школа не выписывала.

С начала 1892/93 учебного года учителем работал 24-летний Иоганн Иоганнович Ран (1871-?), выпускник Гальбштадтского центрального училища, свидетельство учителя он получил в Бердянской гимназии в сентябре 1893 г. И. И. Ран был германским поддан-

\footnotetext{
${ }^{15}$ Документ содержит ведомости о сборах за 1902 г. на содержание лесных команд, в которьх меннониты проходили альтернативную службу. В статистику включались все колонии и частные владения меннонитов, с которых взималась плата в обязательном порядке.

${ }^{16}$ Все сведения о начальной школе в Зильберфельде, если нет другой ссылки, взяты из одного архивного дела: РГИА. Ф. 91. Оп. 3. Д. 368. Л. 356-359 об.
} 
ным, меннонит, холост. К январю 1895 г. его учительский стаж составлял пять лет, три из которых проработал в Зильберфельде. Квартиру учителю владельцы хутора предоставляли бесплатно.

С 15 августа 1910 г. по 15 мая 1911 г. учителем в Серебропольской начальной немецкой школе был $Г$. И. Каздор $\phi^{17}$. На новый 1911/1912 учебный год община искала учителя, холостого, как сказано в объявлении, «для школы на 20-25 детей, частично русских и детей различных конфессий» с содержанием в 350 руб. и бесплатной квартирой. Предлагалось по всем вопросам обращаться к Вильгельму Янцену в Зильберфельд. В 1914 г. в Зильберфельде работал Петр Гейнрихс, дипломированный учитель с многолетней практикой, но с марта искал новое место [74. 15. März 1914. S. 11].

Молодые люди могли продолжить образование в центральных училищах, некоторые колонисты направляли детей в гимназии. Традищионно меннониты обучали подростков в центральных училищах в Гальбштадте (открыто в 1835 г., в 1878 г. при училище открылись педагогические классы), Хортице (1842), Гнаденфельде (1857), в коммерческом училище в Гальбштадте. Славилась частная школа в Орлово, в 1860 г. преобразованная в центральное училище. В начале XX в. число центральных училищ в меннонитских поселениях стремительно росло. В 1910 г. офищиально открылось собственное училище и в Шенфельде.

Для повышенного образования девочек имелись женские училища в Хортище и Тиге. В школах Орлово и Тиге на протяжении многих лет работала семейная династия учителей Янцен: Генрих Иоганнович (1844-1904) и его сыновья Иоганн (1868-1917), Генрих (1869-1940), Яков (1878-1950). Последний работал учителем в частной женской школе в Тиге с момента ее открытия в июле 1909 г. В 1910 г. в этой школе училась Елена Янцен, дочь Вильгельма Генриховича Янщена (Зилберфельд). Она проживала в доме учителя Якова Генриховича Янщена, который сдавал свои комнаты ученицам. Дом находился совсем рядом со школой и зданием для общественных собраний.

Со временем Шенфельдское училище стало принимать не только юношей, но и девушек. В годы революции и Гражданской войны оно было разграблено бандами.

Последний владелец Зильберфельда. Наиболее заметной фигурой среди владель- цев Зильберфельда был Вильгельм Генрихович Янцен (28 сентября 1858, Зильберфельд 14 октября 1919, Мелитополь), чье имя уже неоднократно упоминалось. Супругой Вильгельма была Елена Ивановна Нейфельд (1863-1931), у них было пятеро детей.

В 1883 г. В. Г. Янцен перенял управление хозяйством в Зильберфельде и, по свидетельствам очевидцев, вскоре превратил его в образцовое, во всем царили порядок и дисциплина. В 1902 г. за ним числилось 1520 дес. земли и ветряная мельница (оценка в 1500 руб.) $[22$, с. 19,22$]$. В 1915 г. в его собственности значился участок в 1518 дес. [24, с. 3]. Земля находилась при хуторе Богородичном, p. Жеребец, пустоши Серебряковке и с. Конские Раздоры Гуляйпольской волости. Кроме того, в соседней Белогорьевской волости в 1901 г. за ним числились участки на хуторе Глиняный размером в 150 и 504 дес.

После смерти старшего брата Якова (1885) и его жены (1891) их два сына состояли под опекой В. Г. Янцена. В 1897 г. сиротам был выделен земельный участок, в документах они значились как наследники Янцена Якова Генриховича. Третья часть хутора Зильберфельд принадлежала Аганете Нейфельд.

Вильгельм Генрихович с увлечением занимался развитием сельского хозяйства в своем имении, улучшением пород лошадей, крупного рогатого скота, свиней. Немецкие лошади, которыми гордились колонисты, прибыв с ними в Россию, со временем требовали улучшения различных качеств, в частности их выносливости. Поэтому в этих целях колонисты охотно использовали рысаков. Особой популярностью в хозяйствах пользовалась бельгийская порода тяжеловозов (арденны). Знаменитая красная немецкая корова молочного направления была широко распространена не только среди колонистов, давала до 200 ведер молока в год. Сбыт молока активно шел вблизи рабочих поселений, жители которых не имели собственного хозяйства. Однако время требовало развития стада мясомолочной направленности. Над этим работал и владелец хутора. Так, в 1912 г. он обратился через газету «Der Botschafter» ко всем желающим приобрести бычков вильстермаршской породы ${ }^{18}$, которых он собирался привезти себе. Постоянно вел наблюдения за погодой, что важно было для работ на пашне. В имении был разбит плодовый сад. Свои сельскохозяйственные наблюдения хозяин публиковал на стра-

\footnotetext{
${ }^{17}$ Каздорф Генрих Иоганнович (23.11.1883, Маргенау Бердянского уезда -?), свидетельство на звание учителя получил 7 мая 1905 г. в Самарской гимназии. В 1920 г. преподавал в пколе Маргенау Омского уезда.

${ }^{18}$ Порода получила название по имени города Вилстер (Wilster) в Шлезвиг-Голшштейне.
} 
ницах наиболее популярных у колонистов газет «Der Botschafter» ${ }^{19}$, «Friedensstimme» [78, S. 11], иногда использовал псевдоним «W. J.». Поэтому неслучайно его избирали в сельскохозяйственный совет уездного земства (10 октября 1906 г. и в сентябре 1912 г.).

В. Г. Янцен активно занимался общественной работой в масштабах волости и уезда, был общественным деятелем в полном смысле слова, работал в земских органах и в учреждениях меннонитского сообщества. Гласный Александровского уездного земства на трехлетия с 1887, 1897, 1912 гт., в 1897 г. заведовал 17-м военно-конным участком, который охватывал Шенфельдскую волость. В 1912 г. избран попечителем Санжаровской народной школы, открытой земством для русского населения в 1893 г. В 1915 г. председатель совета Гуляйпольского общества взаимного кредита.

В качестве председателя меннонитского школьного совета Шенфельдской волости Янцен приложил много сил к тому, чтобы в Шенфельде появилось свое центральное училище. Как уже отмечалось, он возглавлял правление по вопросу открытия училища. Участвовал во встрече представителей меннонитских общин с депутатом Государственной думы Г. А. Бергманом по вопросам шпкол, которая проходила 20 декабря 1907 г. в Екатеринославе [79, S. 3]. Среди присутствовавших были духовный старшина Абрам Герц (Орлово), редактор газеты «Friedensstimme» Абрам Крекер, Петр Эдигер (Гальбштадт), Бернгард Нейфельд (Мунтау), обершульц Гальбштадтской волости Дик, предприниматель И. И. Тиссен (Екатеринослав), П. Тярт (Бергфельд) и В. Г. Янцен (Зильберфельд). На встрече важно было познакомить Бергмана с положением школьного образования меннонитов в целом и внести дополнения в предложенную ранее программу по усовершенствованию дела. В частности, было предложено заменить пункт о назначении учителей на выборность учительского персонала.

В 1908 г. от Шенфельдской общины Вильгельм Генрихович вошел в состав комиссии по учреждению и строительству приюта для душевнобольных «Бетания» [68]. От волости вместе с Яковом Петровичем Нейфельдом, хозяином соседнего имения Эбенфельд, был делегатом на всеобщей конференции меннонитов России (5-6 мая 1910) [75, S. 517]. В ка- честве представителя волости участвовал в съездах уполномоченных меннонитских обществ по делам лесных команд: в Хортице 3-4 мая 1911 г. [74. 1911, № 38, S. 4 6], Гнаденфельде 30-31 мая 1912 г. [71], НовоМолочанске (Ней-Гальбштадт) 28-29 апреля 1916 г. [20, ф. 89 , оп. 1 , д. 3578 , л. $1-1$ об.] и 3-4 мая 1917 г. [50, ф. 821, оп. 133, д. 1012, л. 309 а; д. 319, л. 135].

Регулярно сам Вильгельм, его жена и дети делали взносы на различные нужды меннонитов: для поддержания благотворительных учреждений, в пользу военнослужащих меннонитов, для бедствующих сибирских поселенцев. Так, к 1 января 1912 г. Янцен передал в пользу приюта «Бетания» 100 руб. [80, S. 4], в октябре 1913 г. - два окорока, мешок сушеных фруктов, мешок сушеного чернослива, мешок сушеных груш, мешок хмеля. В одном отчете о пожертвованиях за 1911 г. речь идет о подарках, которые сделали «подруги» (Freundinen). Видимо, речь идет о его двух старших дочерях - Марии и Елене. Девушки передали четыре пары обуви, девять пар нижнего белья, десять рубашек.

Как рачительный хозяин В. Г. Янцен проявлял заботу о работниках в своем имении, одним из первых среди меннонитов построил баню для них. По воспоминаниям дочерей Янцена, для работников готовили горячие обеды, даже окорок в тесте, всегда было молоко. Вильгельм Генрихович помогал крестьянам советом и делом, пользовался большим уважением среди гуляйпольских крестьян. В 1906 г. они хотели выбрать его старшиной Гуляйполя, потому что, с их слов, «этот не станет воровать и не будет дрожать перед земскими чиновниками».

Шенфельдская волость в годы Первой мировой и Гражданской войн. Исчезновение волости. Все меннониты в России, мужчины Шенфельдской волости не были исключением, несли альтернативную службу, в мирное время в лесничествах, в годы войны в основном в качестве санитаров. Призывной пункт для жителей волости находился в с. Гуляйполе. В 1912 г. в общий список призывников Александровского уезда было внесено 20803 чел., в т. ч. 823 немца [1, отд. III, c. 12]. Во время осеннего призыва в октябре 1907 г. все юноши волости, подлежащие мобилизации, были признаны пригодными к несению службы. В список попали: Давид Винс,

\footnotetext{
${ }^{19}$ Например, см.: Drei Tage und drei Nächte unter Schnee gelegen! (Der Botschafter. 1907. 24. Januar. S. 3. O снежных заносах в начале января); Zur Dumawahl (Der Botschafter. 1912, № 59. Опубликованы имена землевладельцев, которых не внесли в список на выборы в Государственную думу); Der Botschafter. 1913. 5(18). April. S. 5 (О посевной в Зильберфельде, прошедшей 11-23 марта).
} 
Иоганн Петерс, Генрих Тиссен, Иоганн Тиссен, Иоганн Фаст, Герхард Шредер, Бернгард Эннс, Гергард Эннс, Герман Эннс, Абрам Янцен [94, S. 68].

Начавшаяся война с Германией потребовала значительных человеческих ресурсов, мобилизация охватила и меннонитов-резервистов. 31 августа 1914 г. в церкви Шенфельда состоялись проводы на фронт первой группы мобилизованных [94, S. 72]. Вскоре за ними последовали новые партии. Сначала их направляли в Москву, со временем основную часть меннонитов, как и других российских немпев, перевели на Кавказский фронт.

С началом войны меннониты волости организовали регулярную помощь солдатским семъям в близлежащих русских поселениях, которая дополняла помощь, выделявшуюся государством. Жены солдат ежемесячно получали от соседей по три пуда зерна, а каждый ребенок до 14 лет - по 20 фунтов. Это была серьезная нагрузка на хозяйства колонистов, поскольку многие из них сами остались без кормильцев, ушедших на фронт. Но это делалось для того, чтобы хоть как-то сгладить нараставшую ненависть к немцам за поражения царской армии на фронте.

Осенью 1914 г. против российских немцев была развязана антинемецкая кампания, которая началась с запрета на использование немецкого языка в общественных местах и с переименования населенных пунктов, а закончилась принятием 2 февраля и 13 декабря 1915 г. так называемых «ликвидационных законов», запрещавших немцам, иностранным гражданам и подданным России, владеть и пользоваться землей. Списки землевладельцев, чьи земли подлежали отчуждению, публиковались на страницах «Екатеринославских губернских ведомостей» начиная с апреля 1915 г. (см. Приложение 2). Проводилось изъятие оружия у колонистов. Так, в начале 1915 г. на хуторе Зильберфельд у В. Г. Янцена были конфискованы два ружья и револьвер, у его сына Вильгельма - ружье и револьвер [50, ф. 821, оп. 133, д. 323, л. 34 об.].

На страницах уже упоминавшейся книги Тевса о Шенфельде описаны две показательные истории применения антинемецких законов осенью 1914 г. Землевладелец Петр Зименс, проживавштий близ станции Пологи, еще до войны купил немецкий аэроплан Этрих-Таубе (Etrich-Taube) ${ }^{20}$, который поль- зовался большой популярностью у военных и гражданских лищ, и совершил на нем несколько полетов. Все знали, что Зименс занимается чем угодно, но только не политикой. Однако война с Германией всех, даже здравомыслящих людей, погрузила в трясину шпиономании. Как же, немец перед войной с Германией покупает немецкий самолет! Зименс был арестован и посажен в тюрьму, а затем выслан в Сибирь [94, S. 74].

Другой случай произошел с Иоганном Бергом, владельцем мельницы из поселка Шенбрун в октябре 1914 г. [94, S. 75-76]. В присутствии русских, приехавших на мельницу для перемола зерна и не желавших встать в очередь, Берг обратился по-немецки к своему мельнику с вопросом, почему тот не идет на обед. Рассерженные необходимостью подчиниться хозяину и стоять в очереди, посетители пригрозили Бергу, что пожалуются на него за то, что тот говорит по-немецки. Бытовой спор, подогретый все более нараставшей антинемецкой истерией в обществе, обернулся драмой для хозяина мельницы. Сначала ему пришлось заплатить штраф 200 руб., а позже он был выслан в Томскую губернию, где пробыл два с половиной года.

С приходом к власти Временного правительства «ликвидационные законы» были отменены. Однако классовая ненависть и антинемецкие настроения, военные неудачи русской армии, а потом и развал армии сыграли свою роль. Все меннонитские хутора Шенфельдской волости, особенно те, что стояли в окружении русских и украинских деревень, стали объектом ненависти бедных слоев, независимо от того, какие отношения были у работодателей и наемных работников. На зажиточных меннонитов обрушилось все недовольство крестьян, копившееся десятилетиями и обострившееся войной. Крестьянское движение возглавил Нестор Махно, а его родное село Гуляйполе стало центром партизанской борьбы, достигшей своей кульминации в 1919-1921 гт. История меннонитских поселений Шенфельдской волости в годы Гражданской войны закончилась исчезновением самой волости - многие владельцы погибли, исчезли хутора. Волость исчезла сначала как социально-хозяйственный организм, а затем и как административно-территориальная единица.

Нестор Иванович Махно (1888-1934; настоящая фамилия Михненко) был младшим,

\footnotetext{
${ }^{20}$ Tayбe (Etrich-Taube) - самолет Первой мировой войны, стал первым в истории авиации бомбардировщиком. Модель была сконструирована авиатором Игнацем Этрихом в 1910 г. Массовое производство началось в 1912-1913 гт., самолет активно продавался за границу. Благодаря своей популярности пользовался спросом не только у военных, но и у гражданского населения. В 1911-1914 гг. самолет и его новые варианты участвовали в спортивных состязаниях.
} 
пятым, сыном в семье крестьянина-бедняка, остался без отца в возрасте 11 месяцев. Официальная биография гласит, что в семь лет он стал подпаском, ходил за коровами и овцами крестьян своего села. С восьми лет пошел в местную начальную школу, окончил три класса церковно-приходской школы. С 11 лет батрачил в «имениях немецких кулаков» и у помещиков. Позже работал маляром на заводе сельхозмашин в Гуляйполе. В 1906 г. был арестован за причастность к движению анархистов-коммунистов.

В числе «немецких кулаков», у кого работал Махно, был В. Г. Янцен (хутор Зильберфельд). Об этом сохранились сведения в семейной истории у потомков Вильгельма Генриховича Янцена (Россия) и потомков его племянника Абрама Яковлевича Янцена (Канада). Потомки того и другого нашли друг друга лишь в 2018 г., не имели контактов с 1924 г., поэтому исключена возможность заимствования сведений. Именно канадская линия Янцен поделилась этими фактами с исследователем истории меннонитов С. Петерсоном (Patterson). Канадский историк затрагивает вопрос об истоках классовой ненависти Махно, в т. ч. на примере службы в Зильберфельде. Вероятно, он является автором англоязычной версии статьи о Несторе Махно в «Википедии» ${ }^{21}$ [86].

В ночь с 1 на 2 марта 1917 г. Махно был освобожден из Бутырки и вернулся на Украину, где возглавил борьбу «за новую свободную жизнь». Вскоре он стал председателем волостного земства и районным комиссаром. Первые шаги в этой борьбе зафиксированы в воспоминаниях самого Махно. Он писал, что в Гуляйполе он созвал съезд крупных и мелких собственников-землевладельцев, у которых были отобраны бумаги («купчие») и сожжены ${ }^{22}[36$, с. 318$] .30$ августа 1917 г. Махно призвал своих сторонников от имени Комитета защиты революции: «разбиться на группы в десять - пятнадцать человек $<. . .>$, и не медлить ни одного часа - облететь весь Гуляйпольский район помещичьих имений, кулацких хуторов и немецких богатых колоний и отобрать у этой буржуазии все огнестрельное оружие, как-то: винтовки, централки, дробовые простые ружья, да из холодного - шашки. Ни пальцем, ни словом не оскорблять самой буржуазии...» $[36$, с. 48$]$.

Разорение хуторян началось еще осенью 1917 г. В сентябре «Черная гвардия» Нестора Махно начала громить экономии и накладывать контрибуции. По воспоминаниям ближайшего сподвижника Махно В. Ф. Белаша, осенью были приняты меры по организации первых коммун: «Двадцать пятого сентября мы созвали волостной съезд и провели свою резолюцию относительно контрибуции и конфискации помещичьих земель в пользу общества. После этого помещики разбежались, а промышленная гуляйпольская буржуазия заплатила нам контрибуцию. Месяц спустя работала типография <...> Некоторые товарищи организовали сельские коммуны в имениях Нейфельда и Классена, а также промышленную коммуну - механическую мастерскую. В сельскохозяйственной анархической коммуне, организованной в 1917 году, разместившейся в имении Классена, в семи верстах южнее Гуляйполя, трудились Рувим Баскин, Феофан Скомский, Алексей Марченко <...> К началу октября 1917 г. на помещичьих и кулацких землях из сельскохозяйственных рабочих и беднейшего крестьянства мы в районе Гуляйполя организовали четыре сельскохозяйственные коммуны, общим числом свыше 700 человек» [11].

По воспоминаниям дочери Якова Петровича Нейфельда, владельца имения Эбенфельд, расположенного близ Гуляйполя, в феврале 1918 г. в их доме «появился Н. Махно со своей бандой». Он был хорошо знаком со всей семьей Нейфельда, «вел себя как друг, но ... отобрал все - землю, скот, машины для обработки земли - все было роздано сельчанам близлежащих деревень <...>. Семьи Шредеров, Классен выехали из своих домов. Начались вооруженные нападения, убийства. Был убит выстрелом через окно 22-летний сын Шредеров ${ }^{23}$ ». С приходом оккупантов Нейфельду дали охрану из австрийских солдат,

\footnotetext{
${ }^{21}$ При обращении к этой статъе 30.10.2018 г. в ней прямо говорилось о службе Махно в имении Зилберфельд у Янщена: «At the age of 11 Makhno began working as an ox driver on the Janzen estate in Silberfeld». В настоящее время эта фраза из статьи исчезла, речь идет липь о каком-то меннонитском имении вообще. Далее в статье, со ссылкой на мемуары, опубликованные в 2011 г., «Nestor Makhno. The Ukrainian Revolution» (Edmonton: Black Cat Press), цитируются слова Махно о том, какую ненависть он испытывал при виде детей хозяина: «At this time I began to experience anger, envy and even hatred towards the landowner and especially towards his children - those young slackers who often strolled past me sleek and healthy, well-dressed, well-groomed and scented; while I was filthy, dressed in rags, barefoot, and reeked of manure from cleaning the calves' barn'). ЭТими «молодыми бездельниками» могли быть племянники и сьн Вильгельма Янщена - Генрих (18), Абрам (14), Вильгельм (13).

${ }^{22}$ Вероятно, речь идет о собрании Гуляйпольского волостного исполкома 22 мая 1917 г.

${ }^{23}$ Сын Д. И. Шредера был убит в ночь с 10-го на 11 июня 1918 г. Об этом сообщала газета «Friedensstimme» 30 ноября 1918 г. (с. 8).
} 
и тогда в его дом приехали семьи родственников Шредеры и Классен. Жили все вместе. Лето 1918 г. прошло для них спокойно [39].

В воспоминаниях адъютанта Махно Алексея Чубенко есть небольшой эпизод о налете на хутор Нейфельда, который описан как рядовое событие в череде ограблений, в т. ч. Жеребецкого банка. «Получив пулемет, нужно [было] достать и средства передвижения. Мы решили сделать налет на одну из экономий очень богатого немца Нейфельда (глухой), где взяли 4 лошади, 1 тачанку и 1 дроги. После налета на экономию Нейфельда мы направились к Днепру» [23, с. 734].

Февраль - март 1918 г. были временем распределения махновцами отобранного у землевладельцев живого и мертвого инвентаря и выделения бывших помещичьих имений для поселения в них добровольцев, крестьян и рабочих, организовавшихся в сельскохозяйственные коммуны. Создание коммун было инициативой анархистов-коммунистов Гуляйполя. Таких объединений в семи-восьмиверстном расстоянии от села было четыре. По району их было больше, но эти четыре Махно организовывал лично. «Все их лучшие здоровые начинания проводились на монх глазах. В серьезных случаях - после совещания со мной, - вспоминал Н. Махно. - Одной из них, пожалуй, самой большой, я уделял два дня в неделю своего физического труда» [34, с. 170-171]. Об этих коммунах писал и П. А. Аршинов: «В семи верстах от Гуляй Поля в бывшей помещичьей экономии, была коммуна, объединявшая гуляйпольскую бедноту. Коммуна эта называлась просто коммуной № 1 гуляйпольских крестьян. Верстах в двадцати от нее находилась коммуна № 2 и коммуна № 3 » [6, с. 85]. Махно числился членом коммуны № 1, которая была создана в имении Гергарда Гергардовича Классена.

В каждой коммуне насчитывалось несколько десятков семей. Земля была поделена между ними по «трудовой норме», живой и мертвый инвентарь достался от бывших владельцев. «Нашлась часть помещиков, - пишет Махно, - кулаков-хуторян и немецких колонистов, которая поняла, что так или иначе, но остаться на долгие годы господами, владеющими тысячами десятин земли, эксплуатируя на ней чужой труд, им уже не удастся. Она сдалась сразу революции и занялась на общих основаниях, т. е. без батраков и без права сдавать землю в аренду, устройством своей общественной жизни...» $[36$, с. 63].

Дальнейшая судьба владельцев имений, ближайших соседей Гуляйполя, известна. Осенью 1918 г. Классены выдали замуж един- ственную дочь Маргариту за подданого Германии Георга Эппа, который был дилером по продаже немецких автомобилей в России. Молодожены и родители Классены эмигрировали в Германию вместе с отступавшими оккупационными войсками. Давид Иванович Шредер был убит бандитами 28 октября 1918 г., когда решил навестить собственное имение. Свидетелем гибели владельца имения был П. Гармс, который и описал это событие [76]. Экономию захватил отряд в 70 человек во главе с Махно. Шредера закололи саблями, уже с мертвого забрали одежду. Убиты были и трое русских из Гуляйполя, пришедшие на работу. Семья Якова Нейфельда и вдова Шредера с детьми под защитой австрийских военных выехали в Блюменорт.

Вероятно, осенью 1917 г. и семья Вильгельма Янцена покинула Зильберфельд, а во время оккупации могла вернуться для решения хозяйственных вопросов. Летом 1918 г. вдова Адама Янцена Мария Янцен пыталась распродать имущество, принадлежавшее ей и ее детям в Зильберфельде. Неоднократно подавала в газету «Friedensstimme» объявление о продаже двух жеребцов арденской породы и их земельного участка [74, № 33-36, 38, 39]. В некрологе В. Г. Янцена есть фраза о том, что осенью 1918 г. Махно называл гуляйпольских крестьян «сынками Василия Андреевича» [99]. Возможно, это подтверждает семейную легенду об участии Махно в отъезде семьи Янцен из имения. Если это так, то Янцены покинули имение осенью 1918 г. Согласно легенде, будто бы Махно предупредил Янцена о необходимости уехать, и в сопровождении верхового от Махно семья покинула дом. 14 октября 1919 г. В. Г. Янцен был убит бандитами в собственной квартире в Мелитополе.

Осенью - зимой 1917 г. шенфельдцы понесли первые потери от действий махновцев. 21 декабря 1917 г. газета «Volksfreund» сообщала о похоронах пяти членов семьи Тиссен. Были застрелены: Генрих Тиссен (осталась жена и пятеро детей), его брат Гергард, Арон Генрихович Тиссен (46 лет, холост), 20-летняя дочь Абрама Тиссена, Петр Гергардович Тиссен - сын Гергарда Гергардовича Тиссена [85]. 29 декабря, со слов вдовы Мартенс, стало известно о новом нападении грабителей на семью Мартенс, был убит их сын Иоганн [88].

В середине апреля 1918 г. Гуляйполе было оккупировано, коммунары оставили хозяйство и бежали на юг. В мае начался возврат имущества бывшим владельцам. Летом 1918 г. отряд Махно отступил к Таганрогу и распался, но с июля началось формирование 
нового отряда, и в августе вновь начались рейды отрядов махновцев по немецким хуторам. Ситуация стала обостряться в связи с уходом оккупационных войскпоздней осенью 1918 г.территория разграбления отрядами Махно расширилась, появились новые жертвы.

16 ноября 1918 г. газета «Friedensstimme» опубликовала большой материал о положении в Екатеринославской губернии, в частности в Шенфельдской волости [97]. Банды махновцев хозяйничали в колониях Александровского и Бахмутского уездов. Были убиты меннониты, русские, германские офицеры. Бандиты нападали на пассажирские поезда на станциях Чаплино, Гайчур. 10 ноября состоялся налет на Шенфельд. Было захвачено волостное правление, анархисты требовали оружие, в заложники взяли братьев Петерс. Жители Шенфельда бежали в Гальбштадт, часть - в Орехов. В Розенфельде нападавшие устроили пожар, было сожжено имение Вильмса (Давидполь близ Софиевки). В имении Соляное братьев Тиссен, погибших в 1917 г., был зарублен управляющий Абрам Шредер. Убит и управляющий соседнего имения Берген. В русском селе Кирилловка повесили священника, а его сына-офицера расстреляли. В деревне Жеребец были убиты многие зажиточные русские. Погиб Герхард Эпп, один из братьев - наследников хозяйства Корнелиуса Эппа вблизи Розенгофа у Софиевки. Семья раньше бежала в Софиевку, но Эпп решил проверить состояние хутора, и как раз в это время в хозяйстве действовал большой отряд анархистов. После долгих издевательств казнили и Абрахама Эппа, кузена братьев Эпп, приехавшего из соседнего хутора. У него осталось 9 детей [72]. 21 ноября в Шенфельд со стороны Софиевки вновь пришла банда Махно. Восемь дней назад лично Махно заверил братьев Петерс, что с ними ничего не случится. Теперь же их склад был разграблен, а сам Герман Петерс убит. Среди погибших в тот день братья Герхард и Петр Шредер - сыновья Герхарда Шредера (Ковалиха) $[95,100]$. Затем отряд двинулся к Петру Гейдебрехту. Лично Махно, представившись под именем Шевченко, друга Махно, требовал у хозяина 15 тыс. рублей. Заступничество работников Гейдебрехта спасло ему жизнь, но его дом был ограблен, лучших шесть лошадей и повозки забрали махновцы [95]. Работники Корнелиуса Нейфельда, Абрама Маттиca, Абрахама Варкентина также повели себя мужественно и заступились за своих хозяев. В этом рейде от рук бандитов погибли Яков Маттис, Яков Классен, Давид Варкентин, на- силию подверглись жена и две дочери Якова Гейдебрехта.

Летом 1919 г. некоторые свидетели, зимовавшие на хуторах, сообщали новые подробности о разграблении хозяйств и гибели людей в 1918 г. Дома бежавших были разорены. Имения Герхарда и Франца Тевс полностью разрушены. Землю махновцы поделили между собой до четырех десятин на каждого, лошадей забрали, инвентарь вывезли. В волости только меннонитов было убито 68 чел. Среди них сын волостного судьи Иоганн Францевич Ремпель, Петр Иоганнович Корнис, Яков Гейдебрехт, Яков Дик, Павел Павлович Рогальский, Яков Яковлевич Эннс, Герхард Герхардович Шредер и его сыновья Герхард, Петр и Вильгельм. Семью Шредер хоронили 8 декабря 1918 г. Бандой руководили Семен Правда и его товарищи Митрофан Науменко и Степан Панченко [92].

Что представляла собой Шенфельдская волость после разбоя махновцев, рассказывает очевидец, побывавший в тех местах в январе 1921 г. «Пришлось проехать много хуторов и несколько немецких колоний, в которых не видно было ни одной живой души; везде были только развалины, следы пожарищ и валялись обломанные части земледельческих машин и локомобилей для паровых молотилок и веялок. Степь лежала кругом заброшенная, не вспаханная, заросшая бурьяном и ковылем. А ведь еще недавно это были житницы, поставлявшие пшеницу за гранишу. Немудрено, что теперь в Александровском и Мариупольском уездах распространено людоедство» $[21$, c. 181].

Разоренная и обезлюдевшая волость как административная единица исчезла в ходе административно-территориальных преобразований 1920-1923 гг. Обследование Екатеринославской губернии в 1924 г. установило, что всего в губернии проживало 88433 немца $(2,96 \%$ от общего населения губернии) $[42$, с. 563$]$, в т. ч. в Запорожском округе 19698 [42, с. 561]. Бывшая Краснопольская волость растворилась при новом районировании, вместо волостей появились сельсоветы. Были собраны сведения и о бывших немецких хуторах, некоторые из которых сохранили прежние названия, но заселены были уже украинцами. В Ореховском районе в Новокарловском сельсовете значился хутор Янщенов (Зеленое Поле), состоявший из 16 хозяйств (101 чел., 444 дес.), в Новоселовском сельсовете - хутор Среброполь (11 хозяйств, 36 чел., 157 дес.) [42, с. 230-231]. В Софиевском районе с прежними названиями существовали украинские хутора Мартенса (9 хозяйств) 
и Петерса (8 хозяйств) [42, с. 250-253]. Земли Блюменфельда отошли к крестьянам с. Преображенка.

Согласно материалам Всесоюзной переписи 1926 г., заметное число немцев проживало в поселениях Гуляйпольского (Гуляйполе - 151 чел. [52, л. 152-153]; Зильберталь (Яблоково) - 237 [52, л. 165]; в некоторых еврейских колониях) и Жеребецкого (Дудниково - 364; Егорьевка - 183; Елизаветовка - 165; Екатеринофельд - 87) [52, л. 244-246, 292] районов. В Ореховском районе отмечен хутор Среброполь Новоселовского сельсовета, в котором проживали 6 русских и 172 украинца $[52$, л. 658].

Очевидец, посетивший в 2010 г. место бывшего Зильберфельда, нашел здесь ровное поле: «Сереброполье. Деревня была полностью разрушена в 1950-е годы. На месте бывшего поселения даже многие годы спустя высятся груды кирпича, которые приготовили для себя русские из близлежащих деревень (для своих домов в русских деревнях). Этот хутор лежал на возвышенности, к востоку от современного поселка „Комсомольское“ Предположительно, поселение находилось у современного пересохшего озерца (в центре, перед плотиной). На этом месте все еще можно обнаружить старые фруктовые деревья, битый кирпич, черепицу с крыш. Вокруг простирается непаханое поле» ${ }^{24}$ [93].

Выводы. История меннонитских поселений Шенфельдской волости дополняет картину заселения и развития Александровского уезда, немцы и меннониты активно участвовали в развитии промышленности и сельского хозяйства. Меннониты, раньше многих других вступившие в новые капиталистические отношения, демонстрировали заметные успехи в развитии различных сторон экономической жизни. Их успешность была не только следствием новых подходов к формам хозяйствования, ее во многом определяла ментальность меннонитов, духовные традиции, сплоченность и мобильность в решении задач. На примере поселенцев волости видно, что территориальная разрозненность имений не была помехой ни для решения социальных, ни для решения духовных и образовательных задач. Слабая развитость промышленных объектов волости из-за дисперсного проживания компенсировалась успешным развитием земледелия в условиях засушливого климата. Однако распыленность владений стала слабым звеном в условиях гражданской войны, когда землевладельцы оказались один на один в неравном противостоянии с озлобленными массами крестьян, причиной озлобленности которых отчасти служили и сами зажиточные хуторяне.

Настоящая публикашия не претендует на исчерпывающее исследование истории волости в мирное время и проблем, связанных с периодом Гражданской войны. В статье поднятые вопросы рассматриваются сквозь призму прошлого отдельно взятых имений и судеб ее жителей. Описательность событий оправдана на данном этапе, т. к. важно было выявить факты взаимоотношения противостоявших друг другу сторон. Привлечение материалов из архивов Запорожья и Днепра может существенно расширить и углубить исследуемую тему.

Населенные пункты Шенфельдской волости (1876 г.) [61]

Приложение 1

\begin{tabular}{|l|c|c|}
\hline \multicolumn{1}{|c|}{ Населенный пункт } & Число душ мужского пола & $\begin{array}{c}\text { Расстояние от призывного пункта } \\
\text { (верст) }\end{array}$ \\
\hline Шенфельд & 17 & 28 \\
\hline Александровка & 8 & 30 \\
\hline Берхфельд [Бергфельд] & 7 & 20 \\
\hline Блюменгоф & 2 & 28 \\
\hline Блюменгоф & 1 & 21 \\
\hline
\end{tabular}

\footnotetext{
${ }^{24}$ «Serebropole. Das Dorf wurde in den 1950er J. ganz zerstört. Auf dem Dorfplatz lagen noch Jahre danach große Ziegelhaufen, die die Russen aus den umliegenden Dörfern für sich vorbereitet hatten (für ihre Häuser irn Russendorf). Dieser Chutor lag auf dem Berg, zum Osten vom heutigen Dorf „Komsomolskoje“. Vermutlich lag das Dorf vor dem heute ausgetrockneten kleinen See (in der Mitte, vor dem Damm). Man kōnnte auf diesem Platz noch alte Obstbâume, Ziegelreste, Dachziegelstükke finden. Rundherum ist alles umgepflügt» «Сереброполье. Деревня была полностью разрушена в 1950-е годы. На месте бывшего поселения даже многие годы спустя высятся груды кирпича, которые приготовили для себя русские из близлежащих деревень (для своих домов в русских деревнях). Этот хутор лежал на возвышенности, к востоку от современного поселка «Комсомольское». Предположительно, поселение находилось у современного пересохшего озерца (в центре, перед плотиной). На этом месте все еще можно обнаружить старые фруктовые деревья, битый кирпиम, черепицу с крып. Вокруг простирается непаханое поле). Комментарий к фото Анатолия Прозорова-Регер, 2010 г. Перевод с нем. яз. нашा.
} 
Окончание приложения 1

\begin{tabular}{|c|c|c|}
\hline Населенный пункт & Число душ мужского пола & $\begin{array}{c}\text { Расстояние от призывного пункта } \\
\text { (верст) }\end{array}$ \\
\hline Блюменталь & 6 & 22 \\
\hline Бломенфельд & 17 & 20 \\
\hline Бломенштейн & 19 & 28 \\
\hline Брудергоф & 20 & 29 \\
\hline Брудерфелшд & 8 & 30 \\
\hline Вейдекроне & 4 & 26 \\
\hline Визенфельц & 28 & 23 \\
\hline Визенфельд & 3 & 25 \\
\hline Визингоф [Визенгоф] & 10 & 30 \\
\hline Гольдштар & 3 & 19 \\
\hline Гоффельд & 2 & 25 \\
\hline Гоффельд & 13 & 26 \\
\hline Грингоф & 10 & 28 \\
\hline Гринфельд & 6 & 31 \\
\hline Гуттердорф & 38 & 17 \\
\hline Зильберфельд & 16 & 27 \\
\hline Иоансгейм & 1 & 20 \\
\hline Клейнфельд & 4 & 30 \\
\hline Ковалиха & 9 & 31 \\
\hline Линденорт & 15 & 23 \\
\hline Мариенфельд & 1 & 15 \\
\hline Мариенфельд & 4 & 30 \\
\hline Рейнбах & 2 & 25 \\
\hline Рейнфельд & 1 & 24 \\
\hline Розенвейзе [Розенвейде] & 9 & 19 \\
\hline Розенгоф & 13 & 21 \\
\hline Рорталь & 2 & 21 \\
\hline Рорбах & 3 & 24 \\
\hline Тигенгоф & 8 & 23 \\
\hline Iингоф [Шенгоф] & 5 & 26 \\
\hline IIтейнталь & 7 & 22 \\
\hline Эбенталь & 7 & 22 \\
\hline Всего мужского пола & 347 & \\
\hline
\end{tabular}

Приложение 2

Поселяне Шенфельда и их имущество (по данным на 1916 г.) ${ }^{25}[56]$

\begin{tabular}{|l|c|c|c|l|}
\hline \multicolumn{1}{|c|}{ ФИО владельца } & Земля (дес.) & Дом & Постройки & \multicolumn{1}{|c|}{ Совладельцы } \\
\hline $\begin{array}{l}\text { Берга Иоганна Иоганновича } \\
\text { наследники }\end{array}$ & 107 & + & + & В общем владении \\
\hline $\begin{array}{l}\text { Брауна Иоганна Иоганновича } \\
\text { наследники }\end{array}$ & 183 & + & + & В общем владении \\
\hline Варкентин Давид Яковлевич & $\begin{array}{c}\text { 1) } 121 \\
\text { 2) } 52\end{array}$ & - & + & \\
\hline Варкентин Иоганн Яковлевич & 97 & - & + & \\
\hline Варкентин Яков Яковлевич & 95 & + & + & \\
\hline
\end{tabular}

\footnotetext{
${ }^{25}$ В официальный список поселян внесены владелцы и их совладельы трех категорий: 1) владельцы земли, домов с надворными постройками, 2) владельцы земельных участков с постройками, 3) владельцы земли. Вероятно, последние не обязательно проживали в Шенфельде, а были причислены к нему.
} 
Продолжение приложения 2

\begin{tabular}{|c|c|c|c|c|}
\hline ФИО владельца & Земля (дес.) & Дом & Постройки & Совладельцы \\
\hline $\begin{array}{l}\text { Варкентина Якова } \\
\text { Абрамовича наследники }\end{array}$ & 400 & - & + & \\
\hline Винс Агата Генриховна & 157 & + & - & \\
\hline Винс Генрих Бернгардович & 54 & - & - & \\
\hline Винс Генрих Бернгардович & 256 & + & + & $\begin{array}{l}\text { Его мать (по второму мужу } \\
\text { Дридгер) }\end{array}$ \\
\hline Винс Франц Генрихович & 270 & + & + & \\
\hline $\begin{array}{l}\text { Гейдебрехт Корнелий } \\
\text { Яковлевич }\end{array}$ & 201 & + & + & \\
\hline Гейдебрехт Яков Яковлевич & 124 & + & + & \\
\hline $\begin{array}{l}\text { Дик } \\
\text { Исаак Леонгардович }\end{array}$ & 193 & + & + & \\
\hline Дик Яков Леонгардович & 153 & + & + & \\
\hline Дик Яков Яковлевич & $\begin{array}{l}\text { 1) } 55 \\
\text { 2) } 45\end{array}$ & $\begin{array}{ll}- \\
-\end{array}$ & $\begin{array}{l}+ \\
-\end{array}$ & $\begin{array}{l}\text { Его жена Дик Елизавета } \\
\text { Абрамовна }\end{array}$ \\
\hline $\begin{array}{l}\text { Дика Иоганна Петровича } \\
\text { наследники }\end{array}$ & 107 & + & + & $\begin{array}{l}\text { Вместе с наследниками И. Д. } \\
\text { Матиса и И. И. Берга }\end{array}$ \\
\hline \multirow{3}{*}{$\begin{array}{l}\text { Дридгер (ур. Янцен) } \\
\text { Екатерина Иоганновна }\end{array}$} & 1) 60 & \multirow{3}{*}{$\begin{array}{l}+ \\
- \\
-\end{array}$} & \multirow{3}{*}{$\begin{array}{l}- \\
- \\
-\end{array}$} & \multirow{3}{*}{$\begin{array}{l}\text { В общем владении с } \\
\text { Янценом Абрамом и Яковом } \\
\text { Иоганновичами }\end{array}$} \\
\hline & 2) 30 & & & \\
\hline & 3) 20 & & & \\
\hline Дридгер Абрам Абрамович & 67 & + & + & \\
\hline Дридгер Иоганн Абрамович & 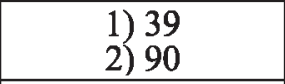 & $\begin{array}{l}+ \\
-\end{array}$ & $\begin{array}{l}+ \\
-\end{array}$ & \\
\hline Дридгер Петр Абрамович & 1) 76 & $\begin{array}{l}- \\
-\end{array}$ & $\begin{array}{l}+ \\
-\end{array}$ & \\
\hline Дридгер Яков Иоганнович & 200 & + & + & \\
\hline Дридгер Яков Иоганнович & 45 & - & - & $\begin{array}{l}\text { Его жена Дридгер Маргарита } \\
\text { Яковлевна }\end{array}$ \\
\hline Классен Яков Яковлевич & $\begin{array}{l}\text { 1) } 56 \\
\text { 2) } 135\end{array}$ & $\begin{array}{l}+ \\
-\end{array}$ & $\begin{array}{l}+ \\
-\end{array}$ & $\begin{array}{l}\text { Его жена Классен Маргарита } \\
\text { Корнелиевна }\end{array}$ \\
\hline $\begin{array}{l}\text { Корнис (по первому } \\
\text { мужу Дридгер) Екатерина } \\
\text { Яковлевна } \\
\end{array}$ & 121 & + & + & \\
\hline \multirow{2}{*}{$\begin{array}{l}\text { Корниса Иоганна Петровича } \\
\text { наследники }\end{array}$} & 1) 366 & \multirow{2}{*}{$\begin{array}{l}+ \\
-\end{array}$} & \multirow{2}{*}{$\begin{array}{l}+ \\
+\end{array}$} & \\
\hline & 2) 107 & & & \\
\hline $\begin{array}{l}\text { Краузе Иоганна } \\
\text { Корнелиевича наследники }\end{array}$ & 100 & + & + & \\
\hline Матис Давид Давидович & 108 & - & + & \\
\hline \multirow{2}{*}{$\begin{array}{l}\text { Матиса Иоганна Давидовича } \\
\text { наследники }\end{array}$} & 1) 123 & \multirow{2}{*}{-} & \multirow{2}{*}{$\begin{array}{l}+ \\
-\end{array}$} & \multirow{2}{*}{$\begin{array}{l}\overline{-} \\
\text { В общем владении с } \\
\text { наследниками И. П. Дика и } \\
\text { И. И. Берга. }\end{array}$} \\
\hline & 2) 22 & & & \\
\hline $\begin{array}{l}\text { Нейфельд Корнелий } \\
\text { Петрович }\end{array}$ & 132 & - & + & \\
\hline Нейфельд Петр Петрович & $\begin{array}{l}\text { 1) } 100 \\
\text { 2) } 100 \\
\text { 3) } 132 \\
\end{array}$ & $\begin{array}{l}- \\
- \\
-\end{array}$ & $\begin{array}{l}+ \\
- \\
-\end{array}$ & \\
\hline $\begin{array}{l}\text { Нейфельда Гергарда } \\
\text { Петровича наследники } \\
\text { (Нейфельд Зара и ее дети: } \\
\text { Яков, Гергард, Иоганн, Анна) }\end{array}$ & $\begin{array}{c}143 \text { и } 57 \text { (в } \\
\text { Шенфельде) } \\
514 \text { при пустоши } \\
\text { Елизаветовка } \\
\end{array}$ & - & $\begin{array}{l}+ \\
-\end{array}$ & \\
\hline Панкрац Анна Яковлевна & 70 & - & - & $\begin{array}{l}\text { В общем владении } \\
\text { с С. Я. Панкрац }\end{array}$ \\
\hline Панкрац Гергард Генрихович & 126 & + & + & $\begin{array}{l}\text { В обшем владении } \\
\text { с И. Г. Панкрацем }\end{array}$ \\
\hline Панкрац Иоганн Генрихович & 126 & + & + & $\begin{array}{l}\text { В общем владении } \\
\text { с Г. Г. Панкрацем }\end{array}$ \\
\hline
\end{tabular}


Продолжение приложения 2

\begin{tabular}{|c|c|c|c|c|}
\hline ФИО владельца & Земля (дес.) & Дом & Постройки & Совладельцы \\
\hline Панкрац Сара Яковлевна & 70 & - & - & $\begin{array}{l}\text { В общем владении с А. Я. } \\
\text { Панкрац }\end{array}$ \\
\hline Петерс Гергард Яковлевич & 1 & - & + & \\
\hline Петерс Франц Гергардович & 100 & + & + & $\begin{array}{l}\text { В общем владении с Г. Г. } \\
\text { Эннсом }\end{array}$ \\
\hline Ремпель Франц Францевич & 1 & - & + & \\
\hline Рогальская Анна Павловна & 71 & - & - & $\begin{array}{l}\text { В общем владении с } \\
\text { Рогальскими Павлом, Марией, } \\
\text { Елизаветой Петровичами }\end{array}$ \\
\hline $\begin{array}{l}\text { Рогальская Елизавета } \\
\text { Павловна }\end{array}$ & 71 & - & - & $\begin{array}{l}\text { В общем владении с } \\
\text { Рогальскими Павлом, Марией, } \\
\text { Анной Петровичами }\end{array}$ \\
\hline Рогальская Мария Павловна & 71 & - & - & $\begin{array}{l}\text { В общем владении с } \\
\text { Рогальскими Павлом, Анной, } \\
\text { Елизаветой Петровичами }\end{array}$ \\
\hline Рогальский Павел Павлович & 64 & + & + & \\
\hline Рогальский Яков Иоганнович & 102 & - & + & \\
\hline $\begin{array}{l}\text { Рогальского } \\
\text { Иоганна Иоганновича } \\
\text { наследники }\end{array}$ & 200 & - & + & \\
\hline $\begin{array}{l}\text { Тевс (по первому мужу Эннс) } \\
\text { Сусанна Яковлевна }\end{array}$ & 50 & + & + & \\
\hline Тевс Гергард Аронович & 199 & + & + & Его дети \\
\hline Тевс Петр Петрович & 2 & - & + & \\
\hline $\begin{array}{l}\text { Тевса Якова Яковлевича } \\
\text { наследники }\end{array}$ & 15 & - & - & \\
\hline Тиссен Николай Яковлевич & $\begin{array}{l}\text { 1) } 200 \\
\text { 2) } 40 \\
\text { 3) } 41 \\
\end{array}$ & $\begin{array}{l}- \\
- \\
-\end{array}$ & $\begin{array}{l}+ \\
- \\
-\end{array}$ & \\
\hline Тиссен Николай Яковлевич & $\begin{array}{l}\text { 1) } 289 \\
\text { 2) } 36 \\
\text { 3) } 39 \\
\text { 4) } 50\end{array}$ & $\begin{array}{l}- \\
- \\
- \\
-\end{array}$ & $\begin{array}{l}+ \\
- \\
- \\
-\end{array}$ & $\begin{array}{l}\text { Его жена Тиссен Анна } \\
\text { Иоганновна и дети: Корелий, } \\
\text { Николай, Абрам, Маргарита }\end{array}$ \\
\hline Тиссен Петр Яковлевич & $\begin{array}{l}\text { 1) } 200 \\
\text { 2) } 5 \\
\text { 3) } 41 \\
\end{array}$ & $\begin{array}{l}- \\
- \\
-\end{array}$ & $\begin{array}{l}+ \\
- \\
-\end{array}$ & \\
\hline Тиссен Яков Яковлевич & $\begin{array}{l}\text { 1) } 200 \\
\text { 2) } 33 \\
\text { 3) } 50\end{array}$ & $\begin{array}{l}- \\
+ \\
-\end{array}$ & $\begin{array}{l}- \\
+ \\
-\end{array}$ & \\
\hline $\begin{array}{l}\text { Тиссена Исаака Иоганновича } \\
\text { наследники }\end{array}$ & 241 & + & + & \\
\hline Фаст Гергард Иоганнович & 100 & + & + & \\
\hline Фаст Иоганн Иоганнович & 150 & + & + & \\
\hline Фаст Корнелий Иоганнович & 100 & + & + & \\
\hline Фризен Анна Абрамовна & 67 & + & + & \\
\hline \multicolumn{5}{|l|}{ Фризен Иоганн Корнелиевич } \\
\hline $\begin{array}{l}\text { Фризен Корнелий } \\
\text { Корнелиевич }\end{array}$ & $\begin{array}{l}\text { 1) } 90 \\
\text { 2) } 12 \\
\text { 3) } 20 \\
\end{array}$ & $\begin{array}{l}- \\
- \\
-\end{array}$ & $\begin{array}{l}+ \\
- \\
-\end{array}$ & $\begin{array}{l}\text { Его жена Фризен Аннета } \\
\text { Иоганновна }\end{array}$ \\
\hline $\begin{array}{l}\text { Шредер Генрих } \\
\text { Вильгельмович }\end{array}$ & 67 & - & - & $\begin{array}{l}\text { В обшем владении с Гергардом } \\
\text { В. Шредером }\end{array}$ \\
\hline Шредер Генрих Гергардович & 57 & - & - & \\
\hline $\begin{array}{l}\text { Шредер Гергард } \\
\text { Вильгельмович }\end{array}$ & 67 & - & - & $\begin{array}{l}\text { В общем владении с Генрихом } \\
\text { В. Шредером }\end{array}$ \\
\hline Шредер Гергард Гергардович & $\begin{array}{c}\text { 1) } 225 \\
\text { 2) } 36 \\
\text { 3) } 10 \\
\text { 4) } 224\end{array}$ & $\begin{array}{l}- \\
- \\
- \\
-\end{array}$ & $\begin{array}{l}+ \\
- \\
- \\
+\end{array}$ & \\
\hline
\end{tabular}


Окончание приложения 2

\begin{tabular}{|c|c|c|c|c|}
\hline ФИО владельца & Земля (дес.) & Дом & Постройки & Совладельцы \\
\hline Эннс Анна Петровна & 129 & - & - & \\
\hline Эннс Генрих Иоганнович & $\begin{array}{l}\text { 1) } 200 \\
\text { 2) } 75\end{array}$ & $\begin{array}{l}+ \\
-\end{array}$ & $\begin{array}{l}- \\
-\end{array}$ & \\
\hline Эннс Гергард Генрихович & $\begin{array}{l}\text { 1) } 228 \\
\text { 2) } 100\end{array}$ & $\begin{array}{l}+ \\
+\end{array}$ & $\begin{array}{l}+ \\
+\end{array}$ & $\begin{array}{l}\text { Его мать Эннс Анна } \\
\text { Гергардовна } \\
\text { В общем владении } \\
\text { с Ф.Г. Петерсом }\end{array}$ \\
\hline $\begin{array}{l}\text { Эннс } \\
\text { Герман Корнелиевич }\end{array}$ & $\begin{array}{l}\text { 1) } 31 \\
\text { 2) } 29\end{array}$ & $\begin{array}{l}- \\
-\end{array}$ & $\begin{array}{l}+ \\
-\end{array}$ & \\
\hline Эннс Иоганн Генрихович & 225 & + & + & \\
\hline Эннс Петр Иоганнович & 21 & - & - & $\begin{array}{l}\text { В общем пользовании с } \\
\text { Эннсами Яковом и Сусанной } \\
\text { Иоганновичами }\end{array}$ \\
\hline Эннс Петр Петрович & 5 & + & + & \\
\hline Эннс Сусанна Иоганновна & 21 & - & - & $\begin{array}{l}\text { В общем пользовании с } \\
\text { Эннсами Яковом и Петром } \\
\text { Иоганновичами } \\
\end{array}$ \\
\hline Эннс Яков Иоганнович & $\begin{array}{l}\text { 1) } 106 \\
\text { 2) } 21\end{array}$ & + & $\begin{array}{l}+ \\
-\end{array}$ & $\begin{array}{l}\text { В общем пользовании с } \\
\text { Эннсами Сусанной и Петром } \\
\text { Иоганновичами }\end{array}$ \\
\hline $\begin{array}{l}\text { Эннса Генриха Генриховича } \\
\text { наследники }\end{array}$ & 233 & + & + & \\
\hline $\begin{array}{l}\text { Эннса Петра Генриховича } \\
\text { наследники }\end{array}$ & 235 & + & + & \\
\hline Янцен Абрам Иоганнович & $\begin{array}{l}\text { 1) } 60 \\
\text { 2) } 30 \\
\text { 3) } 20\end{array}$ & $\begin{array}{l}+ \\
- \\
-\end{array}$ & $\begin{array}{l}+ \\
- \\
-\end{array}$ & $\begin{array}{l}\text { В общем владении с Янщеном } \\
\text { Яковом и Дридгер (ур. Янцен) } \\
\text { Екатериной }\end{array}$ \\
\hline Янцен Арон Иоганнович & 95 & + & + & \\
\hline Янцен Яков Иоганнович & $\begin{array}{l}\text { 1) } 60 \\
\text { 2) } 30 \\
\text { 3) } 20 \\
\end{array}$ & $\begin{array}{l}+ \\
- \\
-\end{array}$ & $\begin{array}{l}+ \\
- \\
-\end{array}$ & $\begin{array}{l}\text { В общем владении с Янценом } \\
\text { Абрамом и Дридгер (ур. } \\
\text { Янцен) Екатериной }\end{array}$ \\
\hline
\end{tabular}

\section{Библиографические ссылки}

1. Адрес-календарь и памятная книжка Екатеринославской губернии на 1912 год. Екатеринослав, 1912. Разд. паг.

2. Айсфельд А. Политическая жизнь меннонитов в России в 1917-1919 годах. Вопросы германской истории: сб. науч. ст. Отв. ред. С. И. Бобылева. Днепропетровск, 2000. С. 223-248.

3. Айсфельд А. Немецкие колонисты Юга Украины в 1917-1918 гг. Вопросы германской истории. Немцы в Украине: материалы укр.-герм. науч. конф., Днепропетровск, 26-29 сент. 1995 г. Отв. ред. С. И. Бобылева. Днепропетровск, 1996. С. 125-133.

4. Айсфельд А. Российские немцы и самоуправление: планы и действительность. Немчы России: сочиально-экономическое и духовное развитие. 1871-1941 г2.: материалы 8-й междунар. науч. конф., Москва, 13-16 окт. 2001 г. Науч. ред. А. А. Герман. М., 2002. С. 30-53.

5. Акт [оценки недвижимости колонистов Шенвизе]. Журнальг Александровского уездного земского собрания 49-й очередной сессии (1904 года). Александровск, 1905. С. 122-129.

6. Аршинов П. История махновского движения (1918-1921 гт.). Берлин, 1923. 258 с.
7. Безносов А. И. Защита или нападение: участие причерноморских немцев в вооруженной борьбе в годы Гражданской войны 1918-1920 гт. Два с половиной века с Россией: актуальные проблемы и дискуссионные вопросы истории и историографии российских немиев: материалы 14-й междунар. науч. конф., Кисловодск, 25-29 сент. 2013 г. Науч. ред. д.и.н., проф. А. А. Герман. М., 2014. С. 350-361.

8. Безносов А. И. К вопросу об участии немецких колонистов и меннонитов в Гражданской войне на юге Украины (1917-1921 гг.). Вопросы германской истории. Немиы в Украине: материалы укр.-герм. науч. конф., Днепропетровск, 26-29 сент. 1995 г. Отв. ред. С. И. Бобылева. Днепропетровск, 1996. С. 112-125.

9. Безносов А. И. Колонистское население и вооруженная борьба на юге Украины (конец 1918 - осень 1920 гг.). Bопросы германской истории: сб. науч. тр. Отв. ред. С. И. Бобылева. Днепропетровск, 2005. C. 71-96.

10. Безносова О. В. Екатеринославская губерния: Terra incognita евангельского движения Российской империи (середина XVIII в. - 1917 г.). Steinhagen: Samenkorn, 2014. 543 c. 
11. Белаш А. В., Белаш В. Ф. Дороги Нестора Махно. Историческое повествование. Киев, 1993. URL https://bookscafe.net/read/belash viktor-dorogi nestora mahno-189947.html\#p14 (дата обрашения 03.03.2020).

12. Бобылева С. И. К вопросу о причинах трагических событий в меннонитских колониях юга Украины в годы Гражданской войны. Российские немцы в иноначиональном окружении: проблемы адаптачии, взаимовлияния, толерантности: материалы междунар. науч. конф., Саратов, 14-19 сент. 2004 г. М., 2005. С. 289-303.

13. Бобылева С. И. На Рейне и Днепре. Опыт непредвзятой германистики: сб. науч. тр. Днепр, 2017. $1016 \mathrm{c}$.

14. Васильчук В. М. Трансформація становища німецького населення Україны в 1917-1919 рр. Вопросы германской истории: сб. науч. ст. Отв. ред. С. И. Бобылева. Днепропетровск, 2002. С. 77-85.

15. Ведомость о состоянии народных училищ в Александровском уезде Екатеринославской губернии за 1866-67 учебный год. Протоколы второй очередной сессии Александровского уездного земского собрания 20-26 сентября 1867 2. Екатеринослав, 1868. C. 252-253.

16. Венгер Н. В. Меннонитское предпринимательство в условиях модернизации Юга России: между конгрегацией, кланом и российским обществом (1789-1920). Днепропетровск, 2009. 700 с.

17. Волости и важнейшие селения Европейской России. Вып. 8. Губернии Новороссийской группы. СПб., 1886. [161] c.

18. Вся Екатеринославская губерния. 1913 год. Екатеринослав, 1913. [6], 68, 389 с.

19. Вся Россия: Русская книга промышленности, торговли, сельского хозяйства и администрации. Торгово-промышленный адрес-календарь Российской империи. СПб., 1899. Разд. паг.

20. Государственный архив Одесской области (ГАОО). Ф. 89. Оп. 1. Д. 3578. Л. 1-1 об.

21. Данилов И., ген. Воспоминания о моей подневольной службе у большевиков. Архив русской революұии, изд. Г. В. Гессеном. Т. 16. Берлин, 1925.

22. Дело о съезде уполномоченных представителей меннонитских волостных и сельских обществ в имении уполномоченного Я. Я. Зудермана 6 и 7 мая 1903 года. Мелитополь, 1903.

23. Дневник Алексея Чубенко (адъютанта Махно). Нестор Махно. Крестьянское двиюение на Украине. 1918-1921. Документы и материалы. Под ред. В. Данилова и Т. Шанина. М., 2006. С. 731-767.

24. Дополнительный список имуществ, находящихся в Екатеринославской губернии в пределах 100-верстной полосы по побережью Азовского моря. Екатеринославские губернские ведомости. 1915. 18 июля. С. 3-5.

25. Екатеринославская губерния. Памятная книжка и адрес-календарь на 1901 г. Екатеринослав, 1900. Разд. паг.

26. Екатеринославский адрес-календарь. 1915 год (1916 год). Екатеринослав, 1915 (1916).

27. Живи и помни... История меннонитских колоний Екатеринославщины. Автор. кол.: С. И. Бобылева, О. В. Безносова, Н. В. Венгер, О. Н. Каковкина, В. К. Клец и др. Днепропетровск, 2006. 379 с.

28. Журналы Александровского земского уездного земского собрания 49-й очередной сессии (1904 года). Александровск, 1905. Разд. паг.
29. Журналы Александровского уездного земского собрания очередной сессии 1888 года. Александровск, 1889. 540, X с.

30. Клибанов А. Меннониты. М.; Л., 1931. 110 с.

31. Лаптев Ю. Н. Немцы и меннониты Юга Украины в Гражданской войне (1918-1920 гг.). Bonросы германской истории: сб. науч. ст. Отв. ред. С. И. Бобылева. Днепропетровск, 2000. С. 249-260.

32. Материалы для военной географии и военной статистики. Военное обозрение Екатеринославской губернии. Сост. В. Павлович. СПб., 1863. 311 с.

33. Материалы для оценки земель Екатеринославской губернии. Т. 2: Александровский уезд. [Екатеринослав], $1902.742 \mathrm{c.}$

34. Махно Н. И. Азбука анархиста. М., 2005. 572 с.

35. Немцы России. Населенные пункты и места поселения: Энциклопедический словарь. Сост. В. Ф. Дизендорф. М., 2006. 470 с.

36. Нестор Махно. Воспоминания. М., 1992. 334 с.

37. Нестор Махно. Крестьянское движение на Украине. 1918-1921. Документы и материалы. Под ред. В. Данилова и Т. Шанина. М., 2006. 1000 с.

38. О ликвидации немецкого землевладения. Журналы Александровского земского уездного земского собрания 50-й очередной сессии 1915 года. Александровск, 1916. С. 54-56.

39. О предках семьи Нейфельд со стороны нашего отца Нейфельд Петра Яковлевича (VI. 1892 - I. 1939). URL: https://chort.square7.ch/FB/rdick05.html (дата обращения 02.02.2020).

40. Об открытии дополнительного кредита на постройку земского дома. Протоколы Александровского уездного земского собрания очередной сессии 1874 года. Екатеринослав, 1875. С. 113-119.

41. Однодневная перепись начальных шпкол империи, произведенная 18 января 1911 г. Вып. IV, ч. 1: Одесский учебный округ. Пг., 1914. [2], 26, 93 с.

42. Описание населенных мест Екатеринославской губернии. На 1 января 1925 г. Екатеринослав, 1925. 636 с.

43. Осташева Н. В. На переломе эпох... Меннонитское сообщество Украины в 1914-1931 гт. М., 1998. 256 с.

44. Отчет инспектора народных училищ А. А. Школьникова о состоянии народных училищ Александровского уезда Екатеринославской губернии за 1898 год. Журналы Александровского уездного земского собрания 34-й очередной сессии (1899 года). Александровск, 1899. С. 197-221.

45. Отчет о действиях Александровской уездной земской управы за 1867/68 отчетный год. Екатеринослав, $1868.103 \mathrm{c}$.

46. Очерки истории немцев и меннонитов юга Украины (конец XVIII - первая половина XIX в.). Автор. коллектив: С. И. Бобылева, Н. В. Бочарова, О. В. Безносова, Л. С. Тутик и др. Днепропетровск, 1999. $232 \mathrm{c}$.

47. Памятная книжка для Екатеринославской губернии на 1860 год. Екатеринослав, 1860. Разд. паг.

48. Памятная книжка Одесского учебного округа на 1913-14 учебный год. Одесса, 1914. 499, LXXI с.

49. Полное собрание законов Российской империн. Собр. 2-е. (1825-1881). СПб., 1830-1884.

50. Российский государственный исторический архив (РГИА).

51. Садоводство. Mатериалы для географии и статистики России, собранные офичерами Генерального итаба. Екатеринославская губерния. СПб., 1862. C. 143-145. 
52. Сапкт-Петербургский филиал Архива РАН (СПбФ АРАН). Ф. 135. Оп. 3. Д. 584. Запорожский округ.

53. Сборник постановлений первого очередного Александровского уездного земского собрания 20-28 октября 1866 г. СПб., 1867. [2], VI, 276 с.

54. Списки населенных мест Российской империи. Т. 13: Екатеринославская губерния с Таганрогским градоначальством. Список населенньх мест по сведениям 1859 года. СПб., 1863. [6], XXXI, 152 с.

55. Списки сельских обществ и общин Екатеринославской губернии. Вып. 1: Александровский уезд. Екатеринослав, 1899. 39 с.

56. Список владельцев недвижимых имуществ, находящихся в Екатеринославской губернии и подлежащих действию Высочайше утвержденных законов от 2 февраля и 13 декабря 1915 г.. Екатеринославские губернские ведомости. Приложение к № 45. 1916, 8 июня.

57. Список лиц, служащих в Одесском учебном округе на 1911/12 учебный год. Ч. 2. Одесса, 1911. Разд. паг.

58. Список мукомольных мельниц России в 1908 году. Ч. 1: Товарные мельницы. СПб., 1909. VIII, 64 с.

59. Список населенных мест Александровского уезда Екатеринославской губернии. Екатеринослав, 1902. 29 c.

60. Список населенных мест Александровского уезда Екатеринославской губернии. Екатеринослав, $1911.43 \mathrm{c}$.

61. Список призывных участков для отправления воинской повинности Екатеринославской губернии Александровского уезда. Протоколы Александровского уездного земского собрания чрезвычайной сессии 14 мая 1876 г. Екатеринослав, 1876. С. 18-19.

62. Список учебных заведений и лищ, служащих в учебных заведениях Екатеринославской дирекции народных училищ на 1902/1903 учебный год. Екатеринослав, 1903. [2], 164, XVI c.

63. Справочная книга «Фабрики и заводы» Екатеринославской губернии на 1902 г. Екатеринослав, 1902. [2], XIII, 310 c.

64. Статистика Российской империи. Волости и гмины 1890 года. Вып 13: Екатеринославская губерния. СПб., 1890.14 с.

65. Черказьянова И. В. Эмиграция в Америку: письма учителя В. П. Нейфельда. Ежегодник МАИИKРH. № 4. М., 2018. С. 268-292.

66. Шевчук Н. А. Газета «Одессаер Рундшау» о проблемах немцев юга Украины в 1918-1919 гт. Вопросы германской истории: сб. науч. ст. Отв. ред. С. И. Бобылева. Днепропетровск, 2008. С. 111-134.

67. Bergen M. The Massacres of Ebenfeld and Steinbach, Borosenko Colony, 1919. Mennonite Historian. 2001, June. № 2. URL: http://www.mennonitehistorian.ca (дата обращения 03.04.2018).

68. Bethania. Mennonitisches Jahrbuch. 1909. S. 89-92.

69. Brandes D. Von den Zaren adoptiert. Die deutschen Kolonisten und die Balkansiedler in Neurußland und Bessarabien. 1751-1914. München, 1993. 549 S.

70. Chortitza. URL: https://chort.square7.ch

71. Der Botschafter. 1912. 8 (21). Juni. S. 3-4.

72. Die Bande Machno. Friedensstimme. 1918. 19. November. S. 4.

73. Ehemaliger Oberschulze der Schönfelder Wolost J.P. Dick † Friedensstimme. 1914. 1 November. S. 8.

74. Friedensstimme. Halbstadt, 1906-1921.
75. Friesen P. M. Geschichte der Alt-Evangelischen Mennoniten Brüderschaft im Russland (1789-1910) im Rahmen der mennonitischen Gesamtgeschichte. Halbstadt, 1911. 777, 154, $103 \mathrm{~S}$.

76. Harms P. Einzelheiten zu der Ermordung David Schröder bei Gulaipol. Friedensstimme. 1918. 30. November. S. 8.

77. Huebert H. Mennonite Estates in Imperial Russia. Winnipeg, 2005. $460 \mathrm{p}$.

78. Janzen W. Zur Zentralschulangelegenheit. Friedensstimme. 1911. 12. November. S. 11.

79. Jekaterinoslaw. Der Botschafter. 1907. 25. Dezember. S. 3.

80. Kassenbericht der Heilanstalt „Bethania“" zum 1. Januar 1912. Der Botschafter. 1912. № 16. S. 4-5.

81. Klippenstem L. The Selbstschutz: a Mennonite Army in Ukraine: 1918-1919. Вопросы германской истории: Немчы Украины и России в конфликтах и компромиссах $X I X-X X$ веков: материалы междунар. науч. конф., Днепропетровск, 24-27 сент. 2007 г. Отв. ред. С. И. Бобылева. Днепропетровск, 2007. С. 175-205.

82. Letkemann P. Mennonite Victims of Revolution, Anarchy, Civil War, Disease and Famme, 1917-1923. Mennonite Historian. 1998, June. № 2. URL: http://www. mennonitehistorian.ca (дата обращения 03.04.2018).

83. List of Mennonites living outside the Molotschna Colony in 1852 compiled by the Molotschna Mennonite District Office. URL : http://www.mennonitegenealogy.com/ russia/1852_Molotschna.htm (дата обращения 15.01.2020).

84. Molotschna School Related Records: 1892-1896. URL: www.mennonitegenealogy.com (дата обращения 10.11.2019)

85. Mord von fünf Personen durch Anarchisten. Molotschnaer Flugblatt (Volksfreund). 1917,

15. Dezember. S. 11.

86. Nestor Makhno. URL: https://en.wikipedia.org/ wiki/Nestor_Makhno (дата обращения 18.02.2020).

87. Nestor Makhno and the Eichenfeld Massacre. A Civil War Tragedy in a Ukrainian Mennonite Village / H. L. Dyck, J. R. Staples, J. B. Toews. Pandora Press, 2004. 115 p.

88. Raubüberfall in Andrepol bei Alexandrowsk. Volksfreund. 1918. 24. Januar. S. 7.

89. Reger A., Plett D. Diese Steine. Die Russlandmennoniten. Steinbach, 2001. 694 S.

90. Russian Mennonite Genealogical Resources. URL: (http://www.mennonitegenealogy.com/russia/

91. Schönfeld. Friedensstimme. 1912. 25. November. S. 6.

92. Schönfelder Wolost. Friedensstimme. 1919. 12. Juli. S. 7-8.

93. Serebropole. URL: http://chort.square7.ch/BSfB. htm (дата обращения 25.10.2017).

94. Töws G. Schönfeld. Werde- und Opfergang einer deutschen Siedlung in der Ukrame. Winnipeg, 1939. $103 \mathrm{~S}$.

95. Ueber die schwierige Mordgeschichte bei Schönfeld. Friedensstimme. 1918. 4. Dezember. S. 7.

96. Unruh B. H. Die niederländisch-niederdeutschen Hintergründe der mennonitischen Ostwanderung im 16., 18. und 19. Jahrhundert. Karlsruhe: Im Selbstverlag, 1955. 432 S.

97. Unruhen im Jekaterinoslawer Gouvernement. Friedensstimme. 1918. 16. November. S. 6-7.

98. Wiens B. B. Silberfeld. Friedensstimme. 1911. 10. Dezember. S. 9.

99. Wilhelm Janzen $\dagger$ Friedensstimme. 1919. 16. November. S. 8.

100. Zur Mordaffäre in der Schönfelder Wolost. Friedensstimme. 1918. 30. November. S. 7. 


\section{References}

1. Adres-kalendar' i pamyatnaya knizhka Ekaterinoslavskoj gubernii na 1912 god. Ekaterinoslav, 1912 (in Russian).

2. Ajsfel'd A. Politicheskaya zhizn' mennonitov v Rossii v 1917-1919 godah. Voprosy germanskoj istorii: Sb. nauch. st. Otv. red. S. I. Bobyleva. Dnepropetrovsk, 2000 (in Russian).

3. Ajsfel'd A. Nemeckie kolonisty YUga Ukrainy v 1917-1918 gg. Voprosy germanskoj istorit. Nemcy $v$ Ukraine: Materialy ukr.-germ. nauch. konf., Dnepropetrovsk, 26-29 sent. 1995 g. Otv. red. S. I. Bobyleva. Dnepropetrovsk, 1996 (in Russian).

4. Ajsfel'd A. Rossijskie nemcy i samoupravlenie: plany i dejstvitel'nost'. Nemcy Rossii: social'noekonomicheskoe $i$ duhovnoe razvitie. 1871-1941 gg.: Materialy 8-j mezhdunar. nauch. konf., Moskva, 13-16 okt. 2001 g. / Nauch. red. A. A. German. M., 2002 (in Russian).

5. Akt [ocenki nedvizhimosti kolonistov SHenvize]. ZHurnaly Aleksandrovskogo uezdnogo zemskogo sobraniya 49-j ocherednoj sessit (1904 goda). Aleksandrovsk, 1905 (in Russian).

6. Arshinov P. Istoriya mahnovskogo dvizheniya (1918-1921 gg.). Berlin, 1923 (in Russian).

7. Beznosov A. I. Zashchita ili napadenie: uchastie prichernomorskih nemcev $\mathrm{v}$ vooruzhennoj bor'be $\mathrm{v}$ gody Grazhdanskoj vojny 1918-1920 gg. Dva s polovinoj veka s Rossiej: aktual'nye problemy $i$ diskussionnye voprosy istorii $i$ istoriografii rossijskih nemcev: Materialy 14-j mezhdunar. nauch. konf., Kislovodsk, 25-29 sent. 2013 g. / Nauch. red. d.i.n., prof. A. A. German. M., 2014 (in Russian).

8. Beznosov A. I. K voprosu ob uchastii nemeckih kolonistov i mennonitov $v$ Grazhdanskoj vojne na yuge Ukrainy (1917-1921 gg.). Voprosy germanskoj istorii. Nemcy $v$ Ukraine. Dnepropetrovsk, 1996 (in Russian).

9. Beznosov A. I. Kolonistskoe naselemie i vooruzhennaya bor'ba na yuge Ukrainy (konec 1918 osen' 1920 gg.). Voprosy germanskoj istorii: Sb. nauch. tr. Otv, red. S. I. Bobyleva. Dnepropetrovsk, 2005 (in Russian).

10. Beznosova O. V. Ekaterinoslavskaya guberniya: Terra incognita evangel'skogo dvizheniya Rossijskoj imperii (seredina XVIII v. - 1917 g.). Steinhagen: Samenkorn, 2014 (in Russian).

11. Belash A. V., Belash V. F. Dorogi Nestora Mahno. Istoricheskoe povestvovanie. Kiev, 1993. URL: https://bookscafe.net/read/belash_viktor-dorogi_nestora mahno-189947.html\#p14 (data obrashcheniya 03.03.2020) (in Russian).

12. Bobyleva S. I. K voprosu o prichinah tragicheskih sobytij v mennonitskih kolomiyah yuga Ukrainy $\mathrm{v}$ gody Grazhdanskoj vojny. Rossijskie nemcy $v$ inonacional'nom okruzhenit: problemy adaptacii, vzaimovliyaniya, tolerantnosti: Materialy mezhdunar. nauch. konf., Saratov, 14-19 sent. 2004 g. M., 2005 (in Russian).

13. Bobyleva S. I. Na Rejne i Dnepre. Opyt nepredvzyatoj germanistiki: Sb. nauch. tr. Dnepr, 2017 (in Russian).

14. Vasil'chuk V. M. Transformaciya stanovishcha nimec'kogo naselennya Ukraîny v 1917-1919 rr. Voprosy germanskoj istorii: Sb. nauch. st. / Otv. red. S. I. Bobyleva. Dnepropetrovsk, 2002 (in Russian).
15. Vedomost' o sostoyanii narodnyh uchilishch $\mathrm{v}$ Aleksandrovskom uezde Ekaterinoslavskoj gubernii za 1866-67 uchebnyj god. Protokoly vtoroj ocherednoj sessii Aleksandrovskogo uezdnogo zemskogo sobraniya 20-26 sentyabrya $1867 \mathrm{~g}$. Ekaterinoslav, 1868 (in Russian).

16. Venger N. V. Mennomitskoe predprinimatel'stvo v usloviyah modernizacii YUga Rossii: mezhdu kongregaciej, klanom i rossijskim obshchestvom (1789-1920). Dnepropetrovsk, 2009 (in Russian).

17. Volosti i vazhnejshie seleniya Evropejskoj Rossii. Vyp. 8. Gubernii Novorossijskoj gruppy. SPb., 1886 (in Russian).

18. Vsya Ekaterinoslavskaya guberniya, 1913 god. Ekaterinoslav, 1913 (in Russian).

19. Vsya Rossiya: Russkaya kniga promyshlennosti, torgovli, sel'skogo hozyajstva $\mathbf{i}$ administracii. Torgovopromyshlennyj adres-kalendar' Rossijskoj imperii. SPb., 1899 (in Russian) (in Russian).

20. Gosudarstvennyj arhiv Odesskoj oblasti (GAOO).

21. Danilov I., gen. Vospominaniya o moej podnevol'noj sluzhbe u bol'shevikov. Arhiv russkoj revolyucii, izd. G. V. Gessenom. T. 16. Berlin, 1925 (in Russian).

22. Delo o s»ezde upolnomochennyh predstavitelej mennonitskih volostnyh i sel'skih obshchestv $\mathrm{v}$ imenii upolnomochennogo YA. YA. Zudermana 6 i 7 maya 1903 goda. Melitopol', 1903 (in Russian).

23. Dnevnik Alekseya CHubenko (ad»yutanta Mahno). Nestor Mahno. Krest'yanskoe dvizhenie na Ukraine. 1918-1921. Dokumenty i materialy. Pod red. V. Danilova i T. SHanina. M., 2006 (in Russian).

24. Dopolnitel'nyj spisok imushchestv, nahodyashchihsya $\mathrm{v}$ Ekaterinoslavskoj gubernii v predelah 100-verstnoj polosy po poberezh'yu Azovskogo moray. Ekaterinoslavskie gubernskie vedomosti. 1915. 18 iyulya (in Russian).

25. Ekaterinoslavskaya guberniya. Pamyatnaya knizhka i adres-kalendar' na 1901 g. Ekaterinoslav, 1900 (in Russian).

26. Ekaterinoslavskij adres-kalendar'. 1915 god (1916 god). Ekaterinoslav, 1915 (1916) (in Russian).

27. ZHivi i pomni... Istoriya mennonitskih kolonij Ekaterinoslavshchiny. Avtor. kol.: S. I. Bobyleva, O. V. Beznosova, N. V. Venger, O. N. Kakovkina, V. K. Klec i dr. Dnepropetrovsk, 2006 (in Russian).

28. ZHurnaly Aleksandrovskogo zemskogo uezdnogo zemskogo sobraniya 49-j ocherednoj sessii (1904 goda). Aleksandrovsk, 1905 (in Russian).

29. ZHurnaly Aleksandrovskogo uezdnogo zemskogo sobraniya ocherednoj sessii 1888 goda. Aleksandrovsk, 1889 (in Russian).

30. Klibanov A. Mennonity. M.; L., 1931 (in Russian).

31. Laptev YU. N. Nemcy i mennonity YUga Ukrainy v Grazhdanskoj vojne (1918-1920 gg.). Voprosy germanskoj istorii: Sb. nauch. st. Otv. red. S. I. Bobyleva. Dnepropetrovsk, 2000 (in Russian).

32. Materialy dlya voennoj geografii i voennoj statistiki. Voennoe obozrenie Ekaterinoslavskoj gubernii. Sost. V. Pavlovich. SPb., 1863 (in Russian).

33. Materialy dlya ocenki zemel' Ekaterinoslavskoj gubernii. T. 2: Aleksandrovskij uezd. [Ekaterinoslav], 1902 (in Russian).

34. Mahno N. I. Azbuka anarhista. M., 2005 (in Russian). 
35. Nemcy Rossii. Naselennye punkty i mesta poselemiya: Enciklopedicheskij slovar'. Sost. V. F. Dizendorf. M., 2006 (in Russian).

36. Nestor Mahno. Vospommaniya. M., 1992 (in Russian).

37. Nestor Mahno. Krest'yanskoe dvizhenie na Ukrame. 1918-1921. Dokumenty i materialy. Pod red. V. Danilova i T. SHanina. M., 2006 (in Russian).

38. O likvidacii nemeckogo zemlevlademya. ZHurnaly Aleksandrovskogo zemskogo uezdnogo zemskogo sobraniya 50-j ocherednoj sessii 1915 goda. Aleksandrovsk, 1916 (in Russian).

39. O predkah sem'i Nejfel'd so storony nashego otca Nejfel'd Petra YAkovlevicha (VI. 1892 - I. 1939). URL: https://chort.square7.ch/FB/rdick05.html (data obrashcheniya 02.02.2020) (in Russian).

40. Ob otkrytii dopolnitel'nogo kredita na postrojku zemskogo doma. Protokoly Aleksandrovskogo uezdnogo zemskogo sobraniya ocherednoj sessii 1874 goda. Ekaterinoslav, 1875 (in Russian).

41. Odnodnevnaya perepis' nachal'nyh shkol imperii, proizvedennaya 18 yanvarya 1911 g. Vyp. IV, ch. 1: Odesskij uchebnyj okrug. Pg., 1914 (in Russian).

42. Opisanie naselennyh mest Ekaterinoslavskoj gubernii. Na 1 yanvarya 1925 g. Ekaterinoslav, 1925 (in Russian).

43. Ostasheva N. V. $\mathrm{Na}$ perelome epoh... Mennonitskoe soobshchestvo Ukramy v 1914-1931 gg. M., 1998 (in Russian).

44. Otchet inspektora narodnyh uchilishch A. A. SHkol'nikova o sostoyanii narodnyh uchilishch Aleksandrovskogo uezda Ekaterinoslavskoj gubernii za 1898 god. ZHurnaly Aleksandrovskogo uezdnogo zemskogo sobraniya 34-j ocherednoj sessii (1899 goda). Aleksandrovsk, 1899 (in Russian).

45. Otchet o dejstviyah Aleksandrovskoj uezdnoj zemskoj upravy za 1867/68 otchetnyj god. Ekaterinoslav, 1868 (in Russian).

46. Ocherki istorii nemcev i mennonitov yuga Ukramy (konec XVIII - pervaya polovina XIX v.) / S. I. Bobyleva, N. V. Bocharova, O. V. Beznosova, L. S. Tutik i dr. Dnepropetrovsk, 1999 (in Russian).

47. Pamyatnaya knizhka dlya Ekaterinoslavskoj gubernii na 1860 god. Ekaterinoslav, 1860 (in Russian).

48. Pamyatnaya knizhka Odesskogo uchebnogo okruga na 1913-14 uchebnyj god. Odessa, 1914 (in Russian)

49. Polnoe sobranie zakonov Rossijskoj imperii. Sobr. 2-e. (1825-1881). SPb., 1830-1884.

50. Rossijskij gosudarstvennyj istoricheskij arhiv (RGIA) (in Russian).

51. Sadovodstvo. Materialy dlya geografii $i$ statistiki Rossii, sobrannye oficerami General'nogo shtaba. Ekaterinoslavskaya guberniya. SPb., 1862 (in Russian).

52. Sankt-Peterburgskij filial Arhiva RAN (SPbF ARAN). F. 135. Op. 3. D. 584. Zaporozhskij okrug (in Russian).

53. Sbornik postanovlenij pervogo ocherednogo Aleksandrovskogo uezdnogo zemskogo sobraniya 20-28 oktyabrya $1866 \mathrm{~g}$. SPb., 1867 (in Russian).

54. Spiski naselennyh mest Rossijskoj imperii. T. 13: Ekaterinoslavskaya guberniya $s$ Taganrogskim gradonachal'stvom. Spisok naselennyh mest po svedemyam 1859 goda. SPb., 1863 (in Russian).

55. Spiski sel'skih obshchestv i obshchin Ekaterinoslavskoj gubernii. Vyp. 1: Aleksandrovskij uezd. Ekaterinoslav, 1899 (in Russian).
56. Spisok vladel'cev nedvizhimyh imushchestv, nahodyashchihsya $v$ Ekaterinoslavskoj gubernii i podlezhashchih dejstviyu Vysochajshe utverzhdennyh zakonov ot 2 fevralya i 13 dekabrya $1915 \mathrm{~g}$. Ekaterinoslavskie gubernskie vedomosti. Prilozhenie k № 45. 1916.8 iyunya.

57. Spisok lic, sluzhashchih v Odesskom uchebnom okruge na 1911/12 uchebnyj god. CH. 2. Odessa, 1911 (in Russian).

58. Spisok mukomol'nyh mel'nic Rossii v 1908 godu. CH. 1: Tovarnye mel'nicy. SPb., 1909.

59. Spisok naselennyh mest Aleksandrovskogo uezda Ekaterinoslavskoj gubernii. Ekaterinoslav, 1902 (in Russian)

60. Spisok naselennyh mest Aleksandrovskogo uezda Ekaterinoslavskoj gubernii. Ekaterinoslav, 1911 (in Russian).

61. Spisok prizyvnyh uchastkov dlya otpravleniya voinskoj povinnosti Ekaterinoslavskoj gubernii Aleksandrovskogo uezda. Protokoly Aleksandrovskogo uezdnogo zemskogo sobraniya chrezvychajnoj sessii 14 maya $1876 \mathrm{~g}$. Ekaterinoslav, 1876 (in Russian).

62. Spisok uchebnyh zavedenij i lic, sluzhashchih v uchebnyh zavedeniyah Ekaterinoslavskoj direkcii narodnyh uchilishch na 1902/1903 uchebnyj god. Ekaterinoslav, 1903 (in Russian).

63. Spravochnaya kniga «Fabriki i zavody» Ekaterinoslavskoj gubernii na 1902 g. Ekaterinoslav, 1902 (m Russian).

64. Statistika Rossijskoj imperii. Volosti i gminy 1890 goda. Vyp 13: Ekaterinoslavskaya guberniya (in Russian).

65. CHerkaz'yanova I. V. Emigraciya v Ameriku: pis'ma uchitelya V. P. Nejfel'da. Ezhegodnik MAIIKRN. № 4. M., 2018 (in Russian).

66. SHevchuk N. A. Gazeta «Odessaer Rundshau» o problemah nemcev yuga Ukrainy v 1918-1919 gg. Voprosy germanskoj istoriï: Sb. nauch. st. Otv. red. S. I. Bobyleva. Dnepropetrovsk, 2008 (in Russian).

67. Bergen M. The Massacres of Ebenfeld and Steinbach, Borosenko Colony, 1919. Mennonite Historian. 2001, June. № 2. URL: http://www.mennonitehistorian.ca (data obrashchemya 03.04.2018) (in Russian)

68. Bethania. Mennonitisches Jahrbuch. 1909.

69. Brandes D. Von den Zaren adoptiert. Die deutschen Kolonisten und die Balkansiedler in Neurußland und Bessarabien. 1751-1914. München, 1993.

70. Chortitza. URL: https://chort.square7.ch

71. Der Botschafter. 1912. 8 (21). Juni.

72. Die Bande Machno. Friedensstimme. 1918. 19. November.

73. Ehemaliger Oberschulze der Schönfelder Wolost J.P. Dick + Friedensstimme. 1914. 1. November.

74. Friedensstimme. Halbstadt, 1906-1921.

75. Friesen P. M. Geschichte der Alt-Evangelischen Mennoniten Brüderschaft in Russland (1789-1910) im Rahmen der mennonitischen Gesamtgeschichte. Halbstadt, 1911.

76. Harms P. Einzelheiten $\mathrm{zu}$ der Ermordung David Schröder bei Gulaipol. Friedensstimme. 1918. 30. November.

77. Huebert H. Mennonite Estates in Imperial Russia. Winnipeg, 2005.

78. Janzen W. Zur Zentralschulangelegenheit. Friedensstimme. 1911. 12. November.

79. Eekaterinoslaw. Der Botschafter. 1907. 25. Dezember.

80. Kassenbericht der Heilanstalt „Bethania“ zum 1. Januar 1912. Der Botschafter. 1912. № 16. 
81. Klippenstein L. The Selbstschutz: a Mennonite Army in Ukraine: 1918-1919. Voprosy germanskoj istorii: Nemcy Ukrainy $i$ Rossii $v$ konfliktah $i$ kompromissah $X I X-X X$ vekov: Materialy mezhdunar. nauch. konf., Dnepropetrovsk, 24-27 sent. 2007 g. Otv. red. S. I. Bobyleva. Dnepropetrovsk, 2007.

82. Letkemann P. Mennonite Victims of Revolution, Anarchy, Civil War, Disease and Famine, 1917-1923. Mennonite Historian. 1998, June. № 2. URL: http://www. mennonitehistorian.ca (data obrashcheniya 03.04.2018).

83. List of Mennonites living outside the Molotschna Colony in 1852 compiled by the Molotschna Mennonite District Office. URL: http://www.mennonitegenealogy. com/russia/1852_Molotschna.htm (data obrashcheniya 15.01.2020).

84. Molotschna School Related Records: 1892-1896 URL: www.mennonitegenealogy.com (data obrashcheniya 10.11.2019).

85. Mord von fünf Personen durch Anarchisten. Molotschnaer Flugblatt (Volksfreund). 1917. 15. Dezember.

86. Nestor Makhno. URL: https://en.wikipedia.org/ wiki/Nestor_Makhno (data obrashcheniya 18.02.2020).

87. Nestor Makhno and the Eichenfeld Massacre. A Civil War Tragedy in a Ukrainian Mennonite Village / H. L. Dyck, J. R. Staples, J. B. Toews. Pandora Press, 2004.
88. Raubüberfall in Andrepol bei Alexandrowsk. Volksfreund. 1918. 24. Januar.

89. Reger A., Plett D. Diese Steine. Die Russlandmennoniten. Steinbach, 2001.

90. Russian Mennonite Genealogical Resources URL: (http://www.mennonitegenealogy.com/russia/

91. Schönfeld. Friedensstimme. 1912. 25. November.

92. Schönfelder Wolost. Friedensstimme. 1919. 12. Juli.

93. Serebropole URL: http://chort.square7.ch/BSfB. htm (data obrashcheniya 25.10.2017).

94. Töws G. Schönfeld. Werde- und Opfergang einer deutschen Siedlung in der Ukraine. Winnipeg, 1939.

95. Ueber die schwierige Mordgeschichte bei Schönfeld. Friedensstimme. 1918. 4. Dezember.

96. Unruh B. H. Die niederländisch-niederdeutschen Hintergründe der mennonitischen Ostwanderung im 16., 18. und 19. Jahrhundert. Karlsruhe: Im Selbstverlag, 1955. 97. Unruhen im Jekaterinoslawer Gouvernement. Friedensstimme. 1918. 16. November.

98. Wiens B. B. Silberfeld. Friedensstimme. 1911. 10. Dezember.

99. Wilhelm Janzen $\dagger$ Friedensstimme. 1919. 16. November.

100. Zur Mordaffäre in der Schönfelder Wolost. Friedensstimme. 1918. 30. November. 